\title{
$\square$
}

\section{Four Stories of Quantitative Easing}

\author{
Brett W. Fawley and Christopher J. Neely
}

\begin{abstract}
This article describes the circumstances of and motivations for the quantitative easing programs of the Federal Reserve, Bank of England, European Central Bank, and Bank of Japan during the recent financial crisis and recovery. The programs initially attempted to alleviate financial market distress, but this purpose soon broadened to include achieving inflation targets, stimulating the real economy, and containing the European sovereign debt crisis. The European Central Bank and Bank of Japan focused their programs on direct lending to banks-reflecting the bank-centric structure of their financial systemswhile the Federal Reserve and the Bank of England expanded their respective monetary bases by purchasing bonds. (JEL E51, E58, E61, G12)
\end{abstract}

Federal Reserve Bank of St. Louis Review, January/February 2013, 95(1), pp. 51-88.

Brett W. Fawley is a senior research associate and Christopher J. Neely is an assistant vice president and economist at the Federal Reserve Bank of St. Louis.

(c) 2013, The Federal Reserve Bank of St. Louis. The views expressed in this article are those of the author(s) and do not necessarily reflect the views of the Federal Reserve System, the Board of Governors, or the regional Federal Reserve Banks. Articles may be reprinted, reproduced, published, distributed, displayed, and transmitted in their entirety if copyright notice, author name(s), and full citation are included. Abstracts, synopses, and other derivative works may be made only with prior written permission of the Federal Reserve Bank of St. Louis. 


\section{Fawley and Neely}

characterizes the view that monetary policy can do nothing to stimulate the economy once short-term nominal interest rates approach zero as "demonstrably false."

Recent events have twice tested this claim: first in the early 2000s in Japan and then after the 2007-09 financial crisis in the United States, United Kingdom, Japan, and the euro area. With short rates approaching the zero lower bound in late 2008/early 2009, the Federal Reserve, the Bank of Japan (BOJ), the Bank of England (BOE), and the European Central Bank (ECB) began to pursue less conventional monetary policies-including forms of quantitative easing $(\mathrm{QE})$ to stimulate economic growth. QE policies are those that unusually increase the monetary base, including asset purchases and lending programs. Programs designed to improve credit conditions - that is, credit easing - are a special case of QE if they also increase the monetary base.

Academics have already conducted substantial research on recent QE programs. Stroebel and Taylor (2009), Kohn (2009), Meyer and Bomfim (2010), and Gagnon et al. (2011a,b), for example, study the Fed's 2008-09 QE programs. Gagnon et al's (2011a,b) announcement study finds that large-scale asset purchase (LSAP) announcements reduced U.S. long-term yields. Joyce et al. (2011) find that the BOE's QE program had bond yield effects quantitatively similar to those reported by Gagnon et al. (2011a,b) for the U.S. program. Hamilton and Wu (2011) indirectly calculate the effects of the Fed's 2008-09 QE programs with a term structure model. Neely (2012) evaluates the effect of the Fed's 2008-09 QE on international long bond yields and exchange rates, showing that the effects are consistent with a simple portfolio balance model and long-run purchasing power parity.

Despite this profusion of research on asset purchase programs and QE more generally, there has been little attempt to describe and compare QE programs across central banks. ${ }^{2}$ This article fills that gap by describing and comparing the $\mathrm{QE}$ and related maturity extension programs of the $\mathrm{BOJ}$, the $\mathrm{BOE}$, the Fed, and the ECB. We emphasize, however, that although we draw some limited conclusions about the immediate effects of the programs on financial markets, we do not evaluate the efficacy of the QE programs on the broader economies, as that would require counterfactual models and empirical work well beyond the scope of this article.

The details of the QE programs varied across central banks and depended on the particular structures of their respective economies and the specific motivations for each of the QE actions. For example, this article details the circumstances under which the ECB and BOJ generously lent money to banks to inject reserves into their bank-centric economies, but the Fed and BOE injected reserves into the U.S. and U.K. economies by purchasing bonds. One topic on which this article does not shed light is the extent to which the QE and related programs might have been coordinated; there is no significant public information on the extent of international coordination, if any.

The QE programs in response to the financial crisis differ radically from temporary increases in the monetary base that are occasionally used to provide liquidity for short periods, such as central banks did for Y2K or short-term emergency last-resort lending. Instead, this article discusses the recent episodes in which central banks used QE to stimulate the economy, perhaps by facilitating the functioning of particular financial markets.

The next section discusses potential monetary transmission mechanisms at the zero lower bound, how the mechanisms provide a role for $\mathrm{QE}$, and how they explain the choices involved 
in $\mathrm{QE}$ programs. We then discuss the relationship between $\mathrm{QE}$ and credit easing and describe the Fed, BOJ, BOE, and ECB motivations and programs in the context of a timeline. This is followed by summaries of the amounts and types of asset purchases and our conclusion.

\section{MONETARY TRANSMISSION MECHANISMS AT THE ZERO LOWER BOUND}

Central banks ordinarily conduct monetary policy by buying and selling short-term debt securities to target short-term nominal interest rates. These purchases and sales of assets change both short-term interest rates and the monetary base (the quantity of currency and bank reserves in the economy). For example, a central bank can expand the monetary base in two essentially equivalent ways: by buying bonds from the public or by lending money to the public. Buying bonds reduces the public's bond holdings and increases the amount of currency and bank reserves in the economy. This conventional monetary policy can potentially stimulate the economy through two types of channels: asset price channels (including interest rates) and credit channels.

By purchasing short-term securities, expanding the monetary base, and lowering short-term real interest rates, central banks can affect a variety of asset prices, including exchange rates and stock prices. The changes in asset prices can affect economic decisions. Higher stock prices can directly stimulate consumption and business investment by increasing consumer wealth and making the issuance of new stock more lucrative. A lower foreign exchange value of the domestic currency makes domestic goods more competitive with foreign goods. Lower interest rates encourage borrowing for consumption and investment.

Credit channels require asset price changes to work but they also exploit the fact that easier monetary policy can reduce the effect of certain financial frictions-adverse selection and moral hazard-that hinder borrowing. $\underline{3}$ These problems are especially pervasive during difficult economic times. One example of how economic conditions influence lending through these frictions is that expectations of low profitability can discourage potentially creditworthy borrowers from seeking to borrow at all, but they will not discourage fraudulent borrowers who have no intention of repaying the loan. Thus, the pool of firms and individuals seeking loans will become heavily weighted toward fraudulent borrowers and banks-knowing this-will become increasingly reluctant to make loans. By lowering interest rates and raising stock prices, expansionary monetary policy can improve the balance sheets of firms and consumers, reducing problems of adverse selection and moral hazard.

However, purchasing short-term securities cannot lower interest rates when they are at zero; therefore, increasing the monetary base is not—by itself_-considered an effective stimulus. Because money and bonds become close substitutes, the public can simply choose to hold central bank injections of money as currency "under the mattress," which prevents the additional money from stimulating economic activity. Such a situation is called a liquidity trap and can motivate central banks to focus on specific markets and/or interest rates rather than simply expanding the quantity of money.

In the face of near-zero short-term rates, central banks have recently turned to unconventional policies, which often dramatically increase their monetary bases, to alleviate financial 


\section{Fawley and Neely}

distress or stimulate their economies. Some of these unconventional policies involve direct lending to specific, distressed short-term credit markets, whereas others involve purchases of longterm assets that are intended to reduce real, long-term interest rates.

To understand how monetary policy can potentially affect long-term interest rates, it is useful to decompose the $n$-year real yield on a bond as follows:

$$
y_{t, t+n}=\bar{y}_{t, t+n}+T P_{t, n}-E_{t} \pi_{n}
$$

where $y_{t, t+n}$ is the expected real yield at time $t$ on an $n$-year bond, $\bar{y}_{t, t+n}$ is the average expected overnight rate over the next $n$ years at time $t, T P_{t, n}$ is the term premium on an $n$-year bond at time $t$, and $E_{t} \pi_{n}$ is the expected average rate of inflation over the next $n$ years at time $t$. Long-term real yields can decline in any of three ways: (i) Expected inflation can increase, (ii) the expected policy rate path can fall, and (iii) the term premium can fall.

What sort of monetary policy would change expected inflation, the expected path of short rates, and/or the term premium? First, a central bank can commit to zero interest rates beyond the period that their reaction function would normally call for, what Eggertsson (2006) refers to as "committing to be irresponsible." -5 Such a strategy—often termed "signaling" - is time inconsistent, however: The central bank will want to renege on its commitment and return to its normal policy when conditions improve. The second and third methods-outright asset purchases and bank lending $(\mathrm{QE})$ — can help resolve the apparent time inconsistency of a commitment to an announced policy rate path by changing the central bank's incentives through its balance sheet. A central bank that purchases a sizable quantity of long bonds when long rates are low will see the value of its bond portfolio decline if long rates rise. -6 Similarly, the value of long-term loans will decline as long-term rates rise.

Despite concerns about time consistency, recent policy has incorporated strategies that attempt to commit to a path: The Fed, for example, used five variations of "extended period" language to restrain expectations of policy rate hikes, eventually suggesting that it would maintain its low policy rate until at least mid-2015. On December 12, 2012, the FOMC linked the rate hikes to economic conditions rather than a fixed date. Specifically, the FOMC announced that it expected low rates to be appropriate as long as the unemployment rate was above 6.5 percent, medium-term inflation forecasts stayed below 2.5 percent, and long-run inflation expectations remained anchored..

Central banks can also lower long-term real rates by reducing term premia through asset purchases. This method relies on the portfolio balance channel, which assumes frictions-typically preferred habitat/market segmentation-that (i) preclude perfect arbitrage between long and expected short rates and (ii) permit changes in the maturity composition of nominal government debt to affect asset prices. That is, a central bank's purchase of a quantity of a certain type of risk (i.e., duration) will cause investors to demand less compensation to hold the remaining amount of that type of risk and term premia will fall. Thus, signaling and portfolio balance channels allow asset purchases to lower long real rates and thereby stimulate the economy through the aforementioned asset price and credit channels (Mishkin, 1996). 


\section{QUANTITATIVE EASING VERSUS CREDIT EASING}

This section differentiates credit easing from pure QE. Credit easing policies are intended to reduce specific interest rates/restore market function, while $\mathrm{QE}$ describes any policy that unusually increases the magnitude of central bank liabilities-currency and bank reservesparticularly at the zero bound. Credit easing can entail QE but it specifically targets certain markets and/or interest rates. Federal Reserve Chairman Ben Bernanke termed the Fed's LSAPs "credit easing" because the Fed sought to improve the functioning of long-term bond markets and decrease long-term interest rates rather than simply increase the monetary base. In the same speech, the Chairman stated that "in a pure QE regime, the focus of policy is the quantity of bank reserves, which are liabilities of the central bank; the composition of loans and securities on the asset side of the central bank's balance sheet is incidental" (Bernanke, 2009). ECB executive board member Lorenzo Bini Smaghi describes QE similarly: "When the central bank decides to expand the size of its balance sheet, it has to choose which assets to buy. In theory, it could purchase any asset from anybody" (Bini Smaghi, 2009).

Both the BOJ in the early 2000s and the BOE in the recent episode explicitly described their objectives as expanding bank reserves - that is, $\mathrm{QE}$ - rather than easing credit market conditions. The BOE described its policy in this manner even though its purchases of medium- and longterm gilts would tend to reduce the corresponding interest rates. $\underline{8}$ The ECB and BOJ have recently initiated lending programs that could also be considered "pure" QE in the sense that they targeted reserves and typically accepted a wide range of assets as collateral.

\section{PROGRAM DESCRIPTIONS AND MOTIVATIONS}

This article focuses on the QE programs in response to the subprime crisis, but the BOJ created a precursor to such programs in 2001 in response to an extended period of very sluggish economic conditions. On March 19, 2001, the BOJ changed its main operating target from the uncollateralized overnight call rate to the outstanding balance of "current accounts" (i.e., the quantity of bank reserves). The BOJ announced that it was increasing the target for bank reserves from $¥ 4$ trillion to $¥ 5$ trillion, which was expected to drive the overnight call rate from 0.15 percent to zero.

By 2004, the BOJ had incrementally increased the target for bank reserves to $¥ 30$ trillion to $¥ 35$ trillion while simultaneously purchasing public and private debt and communicating the conditions necessary for exiting the zero interest rate policy (ZIRP). On March 9, 2006, the BOJ ended its official QE regime when it reinstated the uncollateralized overnight call rate as the main policy instrument (setting the target at 0 percent).

The Japanese experience provides few firm conclusions as to the potential for QE as a policy instrument. Ito and Mishkin (2006) argue that the BOJ managed market expectations very poorly from 1998 to 2003, compromising any potential for success. Central banks would soon have another opportunity to employ QE to battle very difficult economic conditions.

Initial Post-Lehman Brothers Responses (September 2008-November 2009)

By late 2008, the delayed indirect effects of the housing price bubble collapse of 2006 had left financial markets dysfunctional, output falling, and short-term rates close to zero. Figure 1 


\section{Fawley and Neely}

\section{Figure 1}

\section{Fed, ECB, BOJ, and BOE Main Policy Rates}

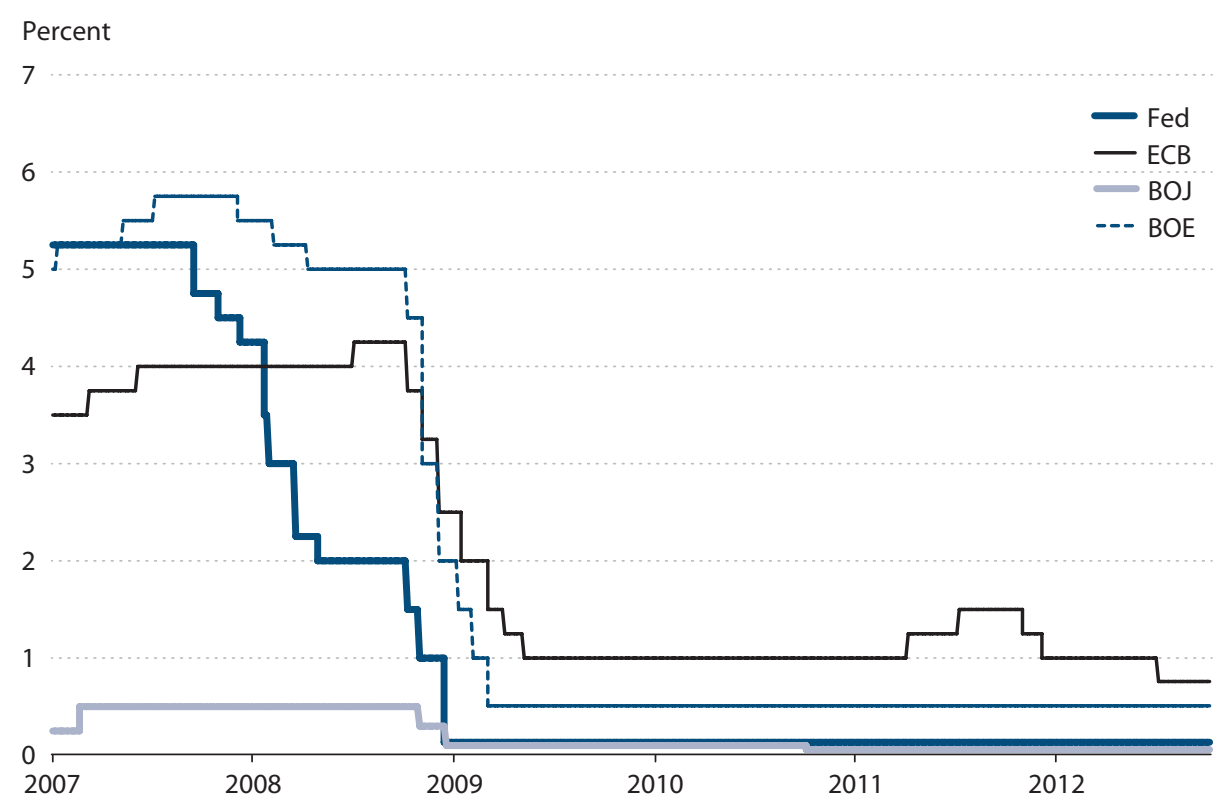

NOTE: The main policy rates for the Fed, ECB, BOJ, and BOE are, respectively, the federal funds target rate, the main refinancing operations fixed/minimum bid rate, the uncollateralized overnight call rate, and the official Bank rate.

SOURCE: Fed, ECB, BOJ, and BOE.

illustrates the convergence of policy rates toward the zero lower bound in late 2008 to early 2009. Initially, the Fed, BOE, BOJ, and ECB policies focused on restoring function to dysfunctional financial markets, but concern soon shifted to stimulating real growth and preventing undesirable disinflation.

The Fed and BOE QE programs fundamentally differed from those of the BOJ and ECB, however, by concentrating on bond purchases rather than lending directly to banks. Bond markets play a relatively more important role than banks in the U.S. and U.K. economies, while banks play a relatively more important role in continental Europe and Japan. Each central bank chose methods to provide liquidity and support the financial system that reflected the structure of its respective economy.

The Bankruptcy of Lehman Brothers. The financial market turmoil-soaring risk premia, illiquidity-that followed Lehman Brother's September 2008 bankruptcy prompted monetary and fiscal authorities to provide emergency dollar liquidity to financial and nonfinancial firms on both sides of the Atlantic. 9 Figure 2 presents a timeline showing dates on which the central banks announced QE asset purchases/lending programs. The first wave of such programs (October 2008-May 2009) came on the heels of a wide range of emergency responses to the Lehman bankruptcy. On September 18, the Fed expanded its foreign exchange swap lines with foreign central banks, and on October 13 it announced that its swap lines with the BOE, ECB, and the Swiss National Bank would accommodate any quantity of funds demanded. On 


\begin{tabular}{llll}
\multicolumn{2}{c}{ Abbreviations Used } \\
ABCP & Asset-Backed Commercial Paper & GSFF & Growth-Supporting Funding Facility \\
APF & Asset Purchase Facility & JGBs & Japanese government bonds \\
APP & Asset Purchase Program & J-REITs & Japanese real estate investment trusts \\
BOE & Bank of England & LSAP & large-scale asset purchase \\
BOJ & Bank of Japan & LTROs & longer-term refinancing operations \\
CBPP & covered bond purchase program & MBS & mortgage-backed securities \\
CFI & corporate finance instruments & MMMF & money market mutual fund \\
CPFF & Commercial Paper Funding Facility & MROs & main refinancing operations \\
ECB & European Central Bank & OIS & overnight indexed swap \\
ETFs & exchange-traded funds & OMTs & outright monetary transactions \\
FOMC & Federal Open Market Committee & QE & quantitative easing \\
FRFA & fixed-rate, full-allotment & SBLF & Stimulating Bank Lending Facility \\
FROs & fixed-rate operations & SFSOs & special-funds-supplying operations \\
GDP & gross domestic product & SMP & Securities Markets Programme \\
GSE & government-sponsored enterprise & ZIRP & zero interest rate policy
\end{tabular}

September 19, the U.S. Treasury guaranteed money market mutual fund (MMMF) deposits and the Fed created the Asset-Backed Commercial Paper (ABCP) Money Market Mutual Fund Liquidity Facility, which lent money to banks for the purpose of purchasing high-quality ABCP. $\underline{10}$ On October 7, the Fed created the Commercial Paper Funding Facility (CPFF) to directly purchase high-quality commercial paper. The ECB announced on September 29, 2008, that on that day it would begin a 1-month "special term refinancing operation...to improve the overall liquidity position of the euro area banking system." Although the Fed previously had responded to the financial crisis (e.g., implementing the Term Auction Facility), these actions were the first unsterilized policy actions - that is, the first Fed actions that were allowed to unusually expand the monetary base (see the boxed insert).

The ECB's Fixed-Rate Tender, Full-Allotment Programs. The 3-month Euribor/overnight indexed swap (OIS) spread widened as financial conditions deteriorated. On October 10, 2008, the spread hit an all-time high of 198 basis points, which reflected the sharp rise in perceived counterparty risk. 11 The ECB responded to these widening spreads on October 15, 2008, with its first measure of QE: The ECB announced it would lend as much as banks wanted at a fixedrate tender-provided the banks had collateral—while also expanding the list of eligible collateral. These fixed-rate tender, full-allotment (FRFA) operations reversed the ECB's conventional policy of offering a fixed allotment of funds at rates determined by the bidding process. $\underline{12}$

The ECB implemented the FRFA liquidity provision through its usual lending procedures. In normal times, the ECB's primary policy instrument is refinancing operations, direct lending to banks against eligible collateral at two maturities. Main refinancing operations (MROs) have a period of two weeks and longer-term refinancing operations (LTROs) have a period of three months. $\frac{13}{}$ In the usual MROs and LTROs, the ECB predetermines the amount of funding available and auctions those funds by price. Under the new policy, the ECB filled all MRO and LTRO 


\section{Fawley and Neely}

\section{Figure 2}

\section{QE Timeline}

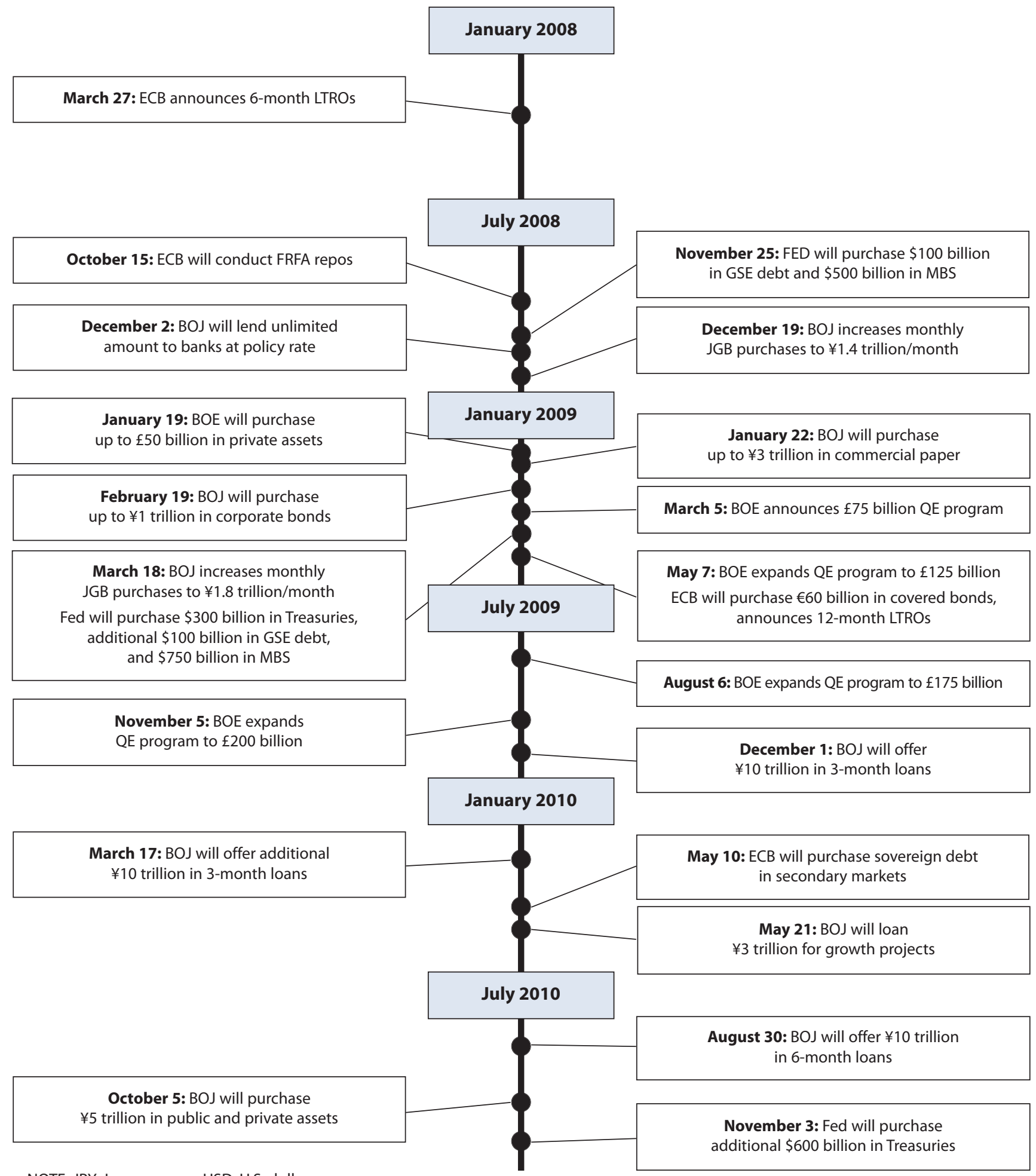

NOTE: JPY, Japanese yen; USD, U.S. dollars. 


\section{Figure 2, cont'd}

\section{QE Timeline}

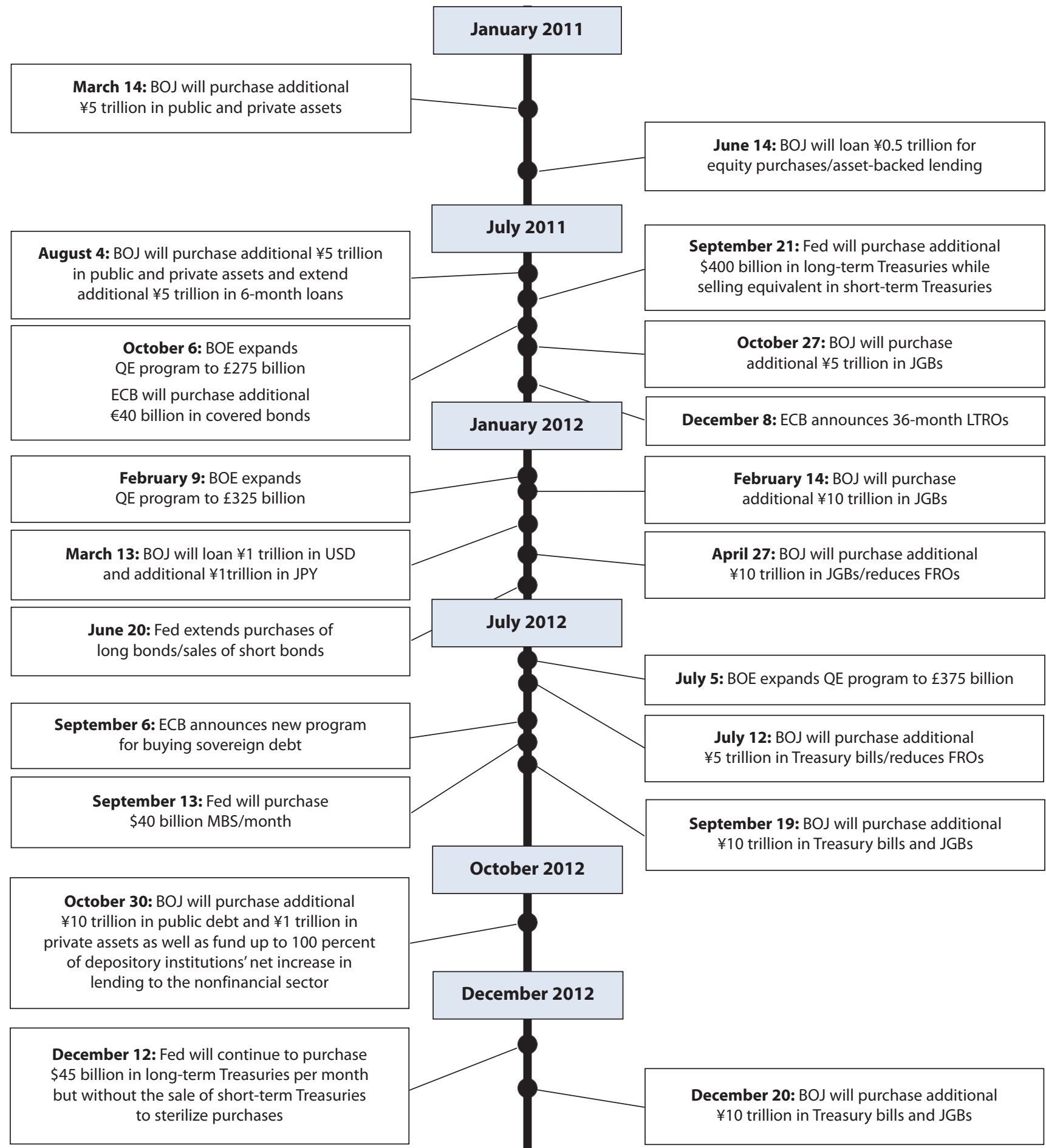

NOTE: FROs, fixed-rate operations; JPY, Japanese yen; USD, U.S. dollars. 


\section{Fawley and Neely}

loan requests at the ECB's primary policy rate, the main refinancing rate. From October 2008 to May 2009, the ECB cut this rate from 4.25 percent to 1 percent. $\frac{14}{}$

Bini Smaghi (2009) calls the FRFA liquidity policy "endogenous credit easing" because banks' demand for liquidity at the fixed-rate tender determines liquidity. Figure 3B shows the spike in lending under MROs and LTROs following the availability of unlimited funds at the fixed rate in October 2008.

The Fed's QE1 Programs. While the ECB expanded bank lending operations, the Federal Reserve pursued outright asset purchases. On November 25, 2008, the Federal Reserve announced plans to purchase $\$ 100$ billion in government-sponsored enterprise (GSE) debt and $\$ 500$ billion in mortgage-backed securities (MBS) issued by those GSEs (Table 1A). 15 On March 18, 2009, the Fed announced additional purchases of $\$ 100$ billion in GSE debt, $\$ 750$ billion in MBS, and $\$ 300$ billion in long-term Treasury securities. Figure 3A illustrates the accumulation of agency and MBS holdings on the Fed balance sheet beginning in November 2008 and long-term Treasuries beginning in March 2009. Figure 4 reveals that these purchases roughly doubled the size of the U.S. monetary base.

The Fed's November 2008 and March 2009 asset purchase programs-commonly called "QE1" - were designed to support the entire economy but they naturally prioritized housing credit markets, which had been especially hard hit by the 2006-08 fall in U.S. real estate prices, sales, and construction. Housing GSE debt and MBS accounted for more than 80 percent of the assets purchased by the Federal Reserve in its first round of QE, or LSAPs; these assets were directly linked to housing market credit. $\frac{16}{}$ The Federal Open Market Committee (FOMC) stated that the goal of the initial LSAPs was to "reduce the cost and increase the availability of credit for the purchase of houses, which in turn should support housing markets and foster improved conditions in financial markets more generally."17 Gagnon et al. (2011a) report that the November 2008 and March 2009 purchases lowered long-term real U.S. interest rates through their effect on term premia. These purchases substantially increased excess bank reserves.

The Bank of Japan's Special-Funds-Supplying Operations. Following closely on the heels of the Fed's November 25 asset purchase release, the BOJ announced on December 2, 2008, that it would lend unlimited amounts to banks at near-zero rates through special-funds-supplying operations (SFSOs), which were much like the ECB's lending operations. The SFSOs offered 3 -month loans to banks at the uncollateralized overnight call rate, which was then at 0.3 percent. The only limit on the size of the loans from the BOJ to banks was the amount of available collateral (commercial paper and corporate debt). The SFSOs, like the ECB's FRFA repurchase agreement (repo) auctions, constituted QE because they increased the monetary base. On December 19,2008 , the BOJ followed this action by lowering the overnight call rate to 0.1 percent and announcing an increase in outright purchases of Japanese government bonds (JGBs) and a new program to purchase corporate financial instruments. $\frac{18}{B O J}$ assets did not increase sharply in December 2008 (see Figure 3D), though the BOJ's balance sheet did begin to expand after this point.

The Bank of England's Programs. After some initial reluctance to engage in credit easing or QE, U.K. authorities announced plans to purchase assets for these purposes in January and March 2009. On January 19, 2009, Her Majesty's (HM) Treasury announced the establishment of the Asset Purchase Facility (APF), which was to be operated by the BOE. The BOE conducted 
Fawley and Neely

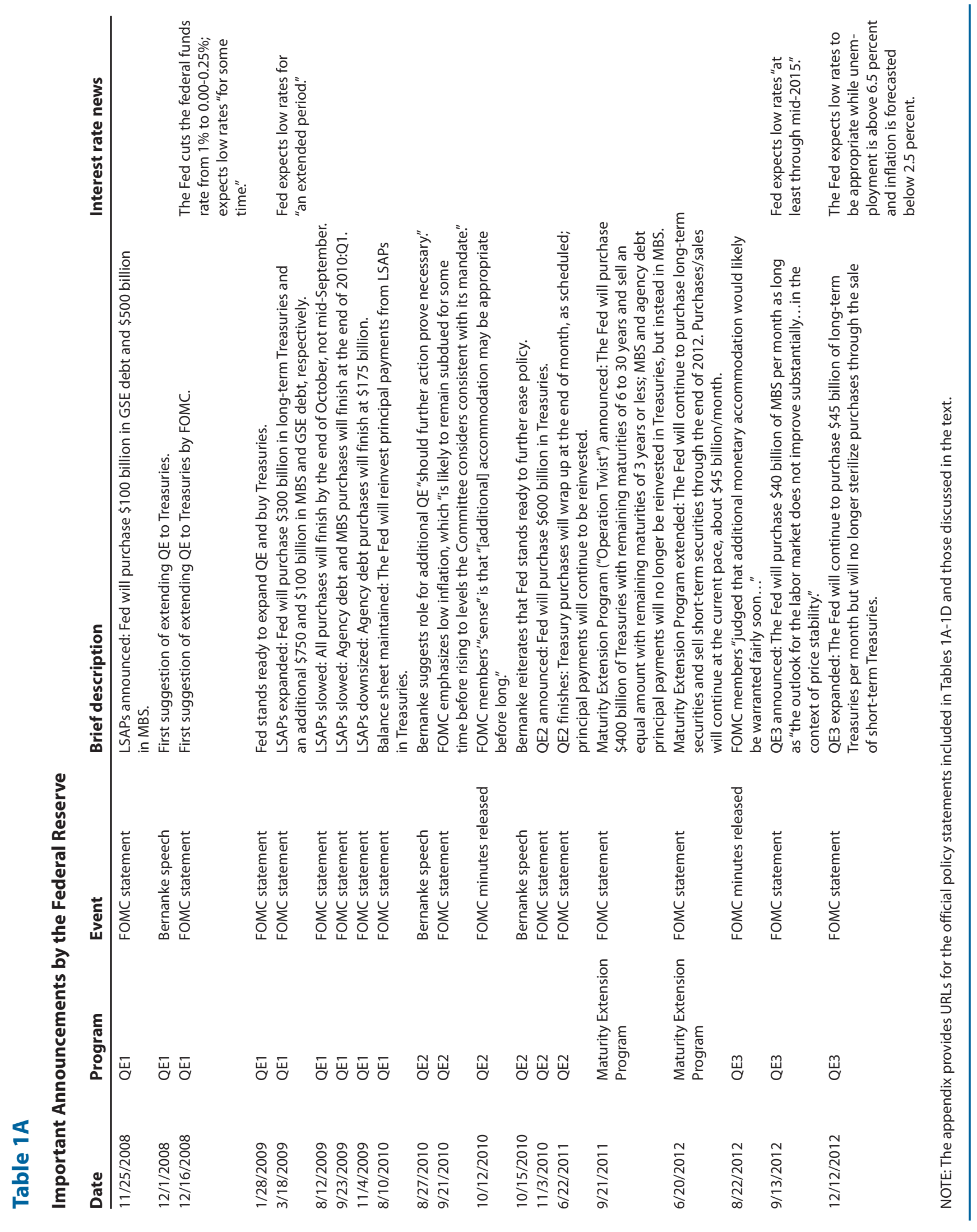




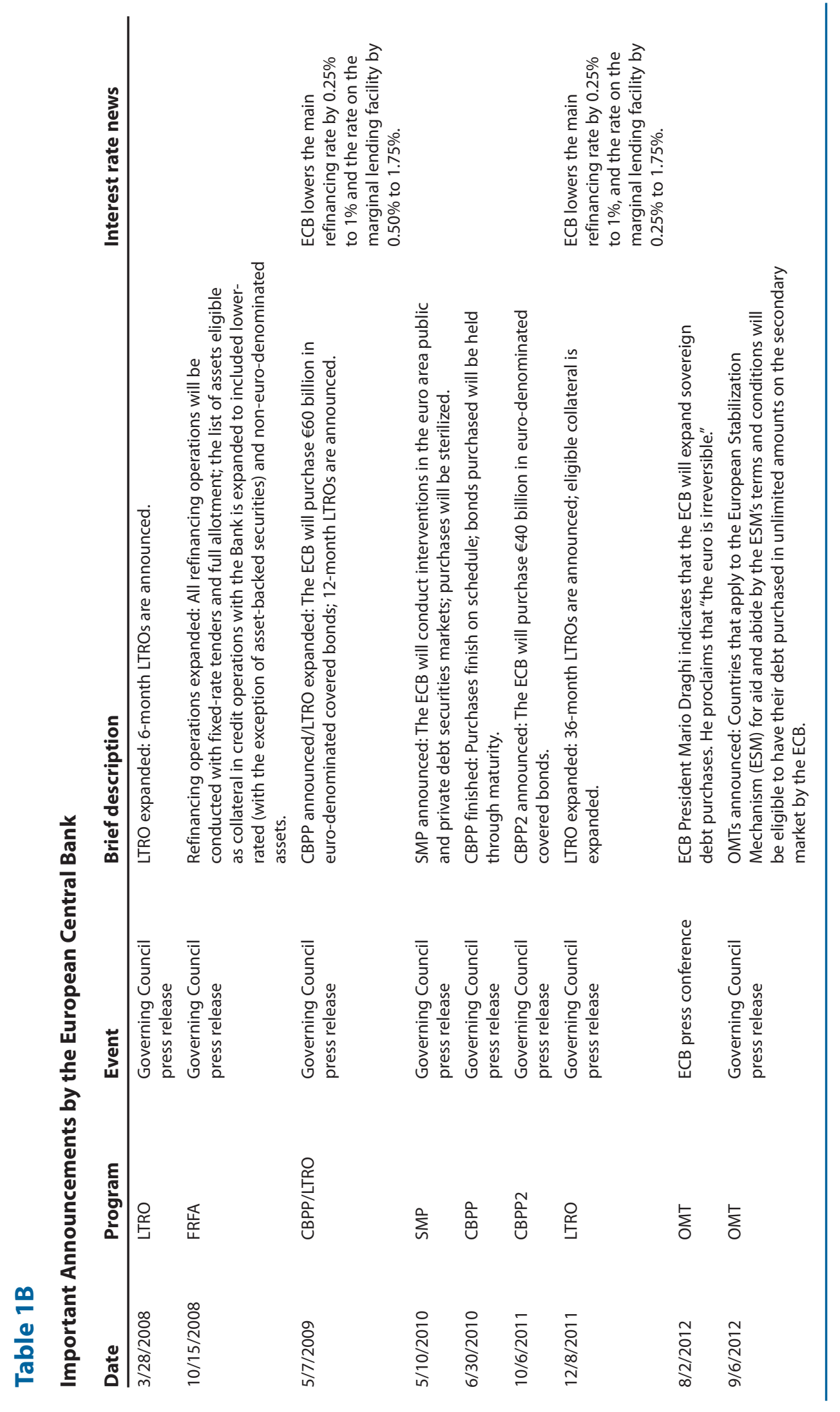


Fawley and Neely

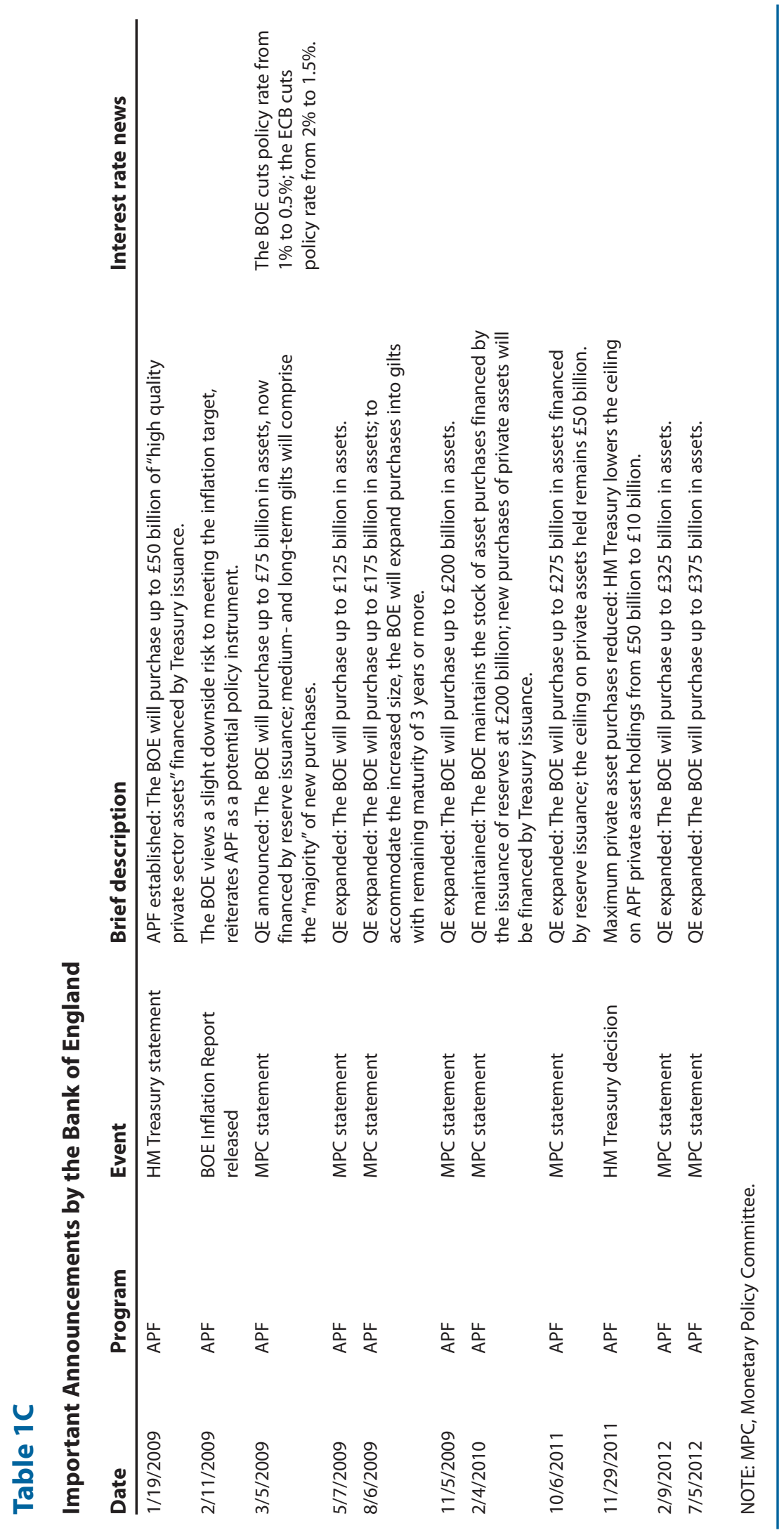




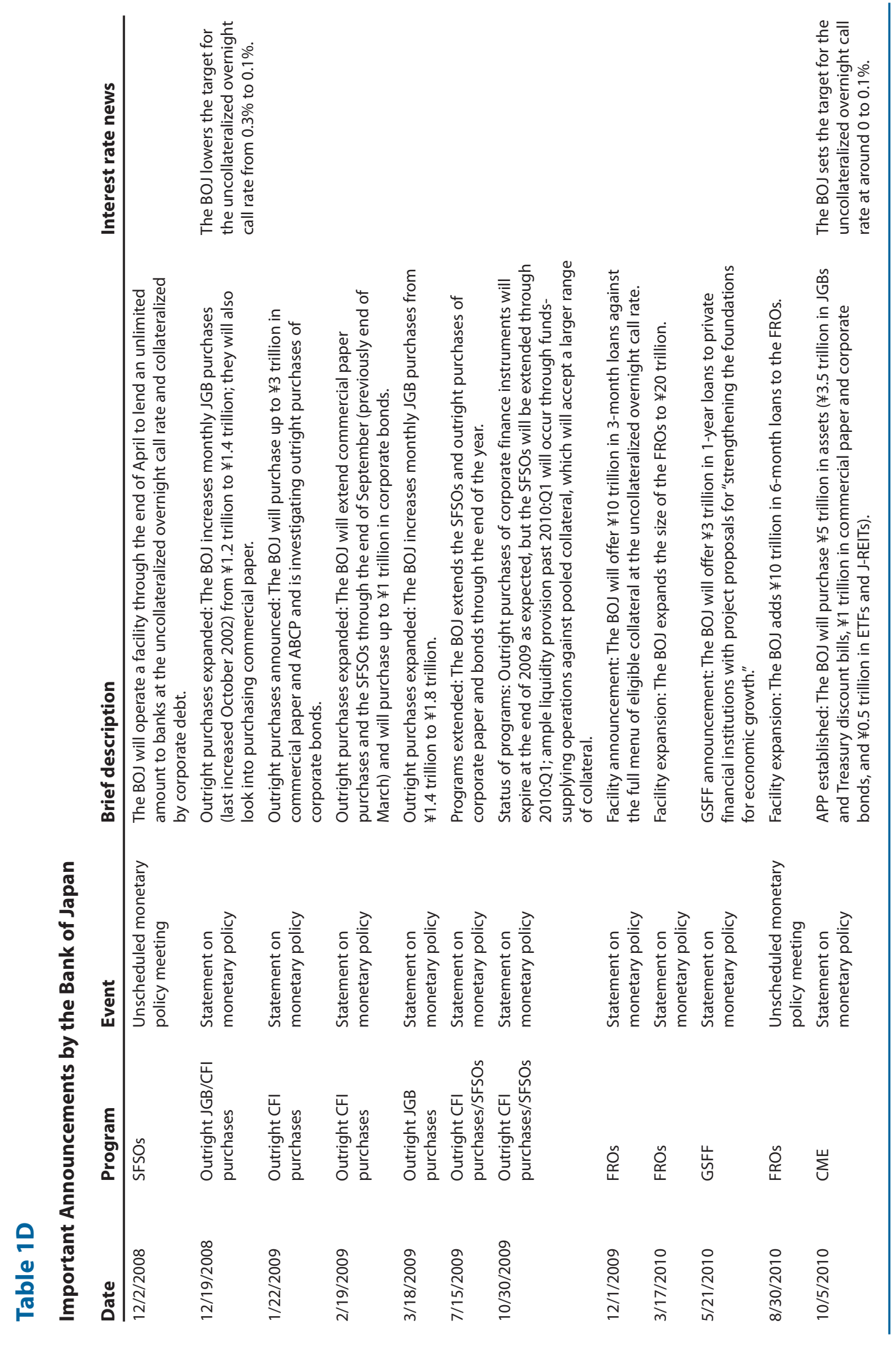




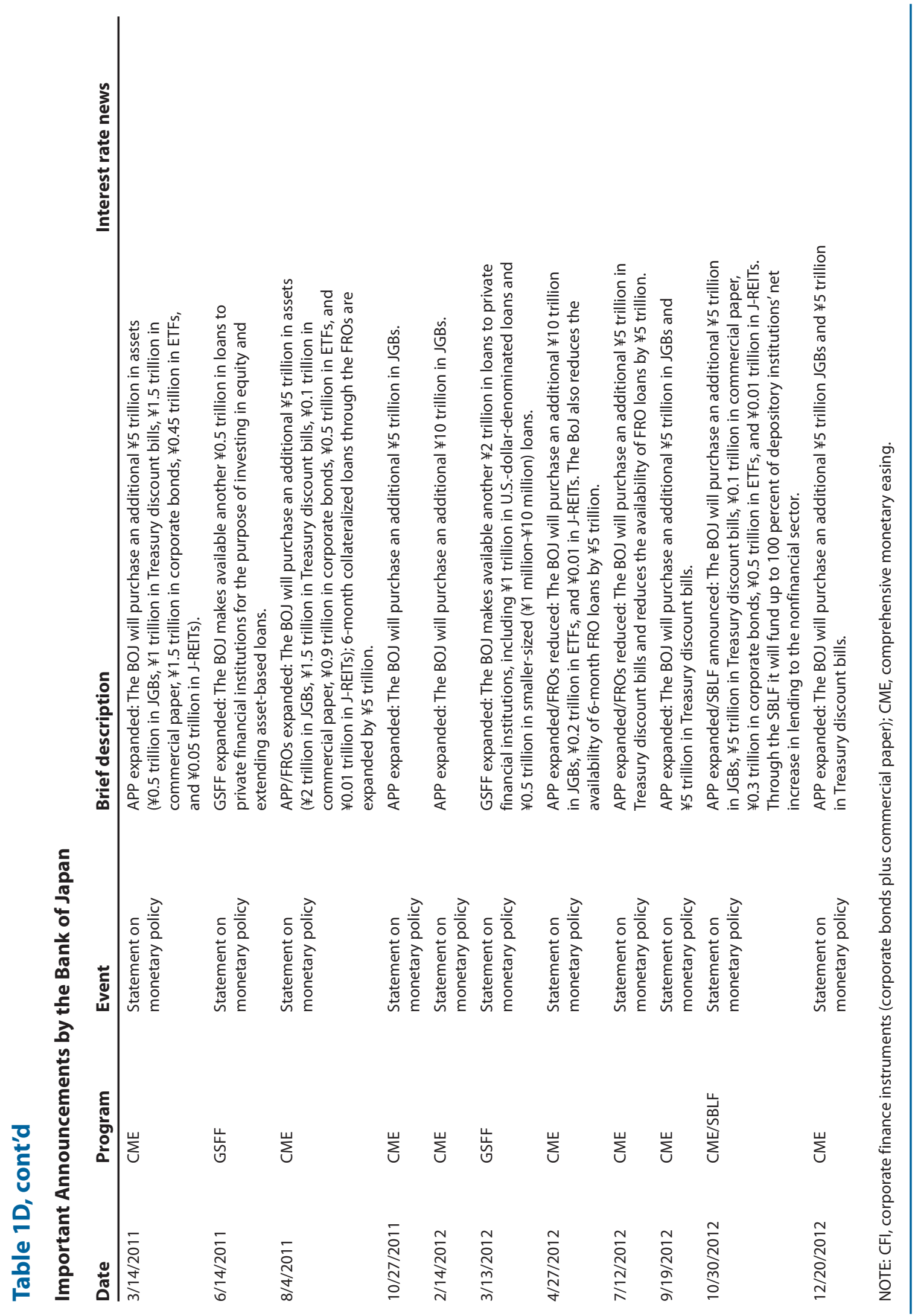




\section{Fawley and Neely}

\section{Figure 3A}

\section{Federal Reserve Bank Assets}

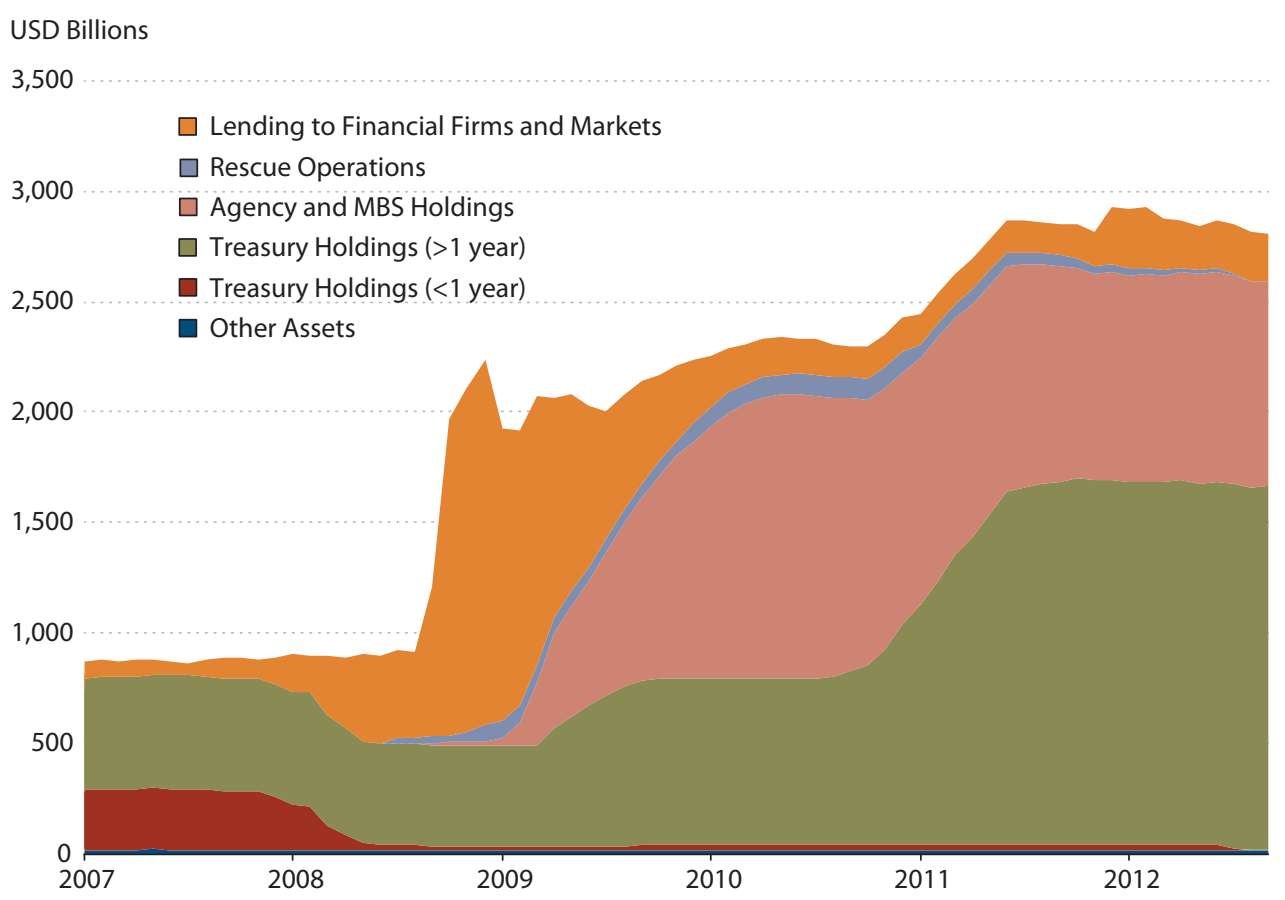

NOTE: "Lending to Financial Firms and Markets" includes repurchase agreements, term auction credit, the CPFF, central bank liquidity swaps, the money market investor funding facility, other loans, and the Term Asset-Backed Securities Loan Facility (TALF). "Rescue Operations" includes net portfolio holdings of Maiden Lanes I, II, and III and preferred interests in AIA Aurora and ALICO Holdings. The figure shows the accumulation of agency and MBS holdings on the Fed balance sheet beginning in November 2008 and long-term Treasury securities beginning in March 2009. SOURCE: Federal Reserve statistical release H.4.1.

two separate and distinct asset purchase programs through this newly established APF: private asset purchases to ease specific credit conditions and more traditional QE for monetary stimulus.

HM Treasury's January 19, 2009, announcement inaugurated the private asset purchase program; it authorized the BOE to buy up to $£ 50$ billion in "high quality private sector assets" to "increase the availability of corporate credit, by reducing the illiquidity of the underlying instruments." 19 Because HM Treasury issued (sold) short-term gilts to finance the purchases, every asset that the BOE purchased was matched by a sale of a short-term gilt and so the BOE's liabilities (the monetary base) did not initially increase. That is, this was not initially QE.

The BOE later described its private asset purchases as "an example of the Bank acting as market maker of last resort" (BOE, 2012). The BOE likewise purchased corporate bonds through a reverse auction; potential counterparties bid on the price at which they would sell assets to the BOE. $\underline{20}$ The program was designed so the BOE's appeal as a counterparty would diminish as market conditions improved.

In a program similar to the Fed's CPFF, the BOE purchased commercial paper at a fixed spread above the local risk-free OIS rates, which established a floor for the price of high-quality commercial paper. In both the United States and United Kingdom, the presence of a market 


\section{Figure 3B}

\section{ECB Assets}

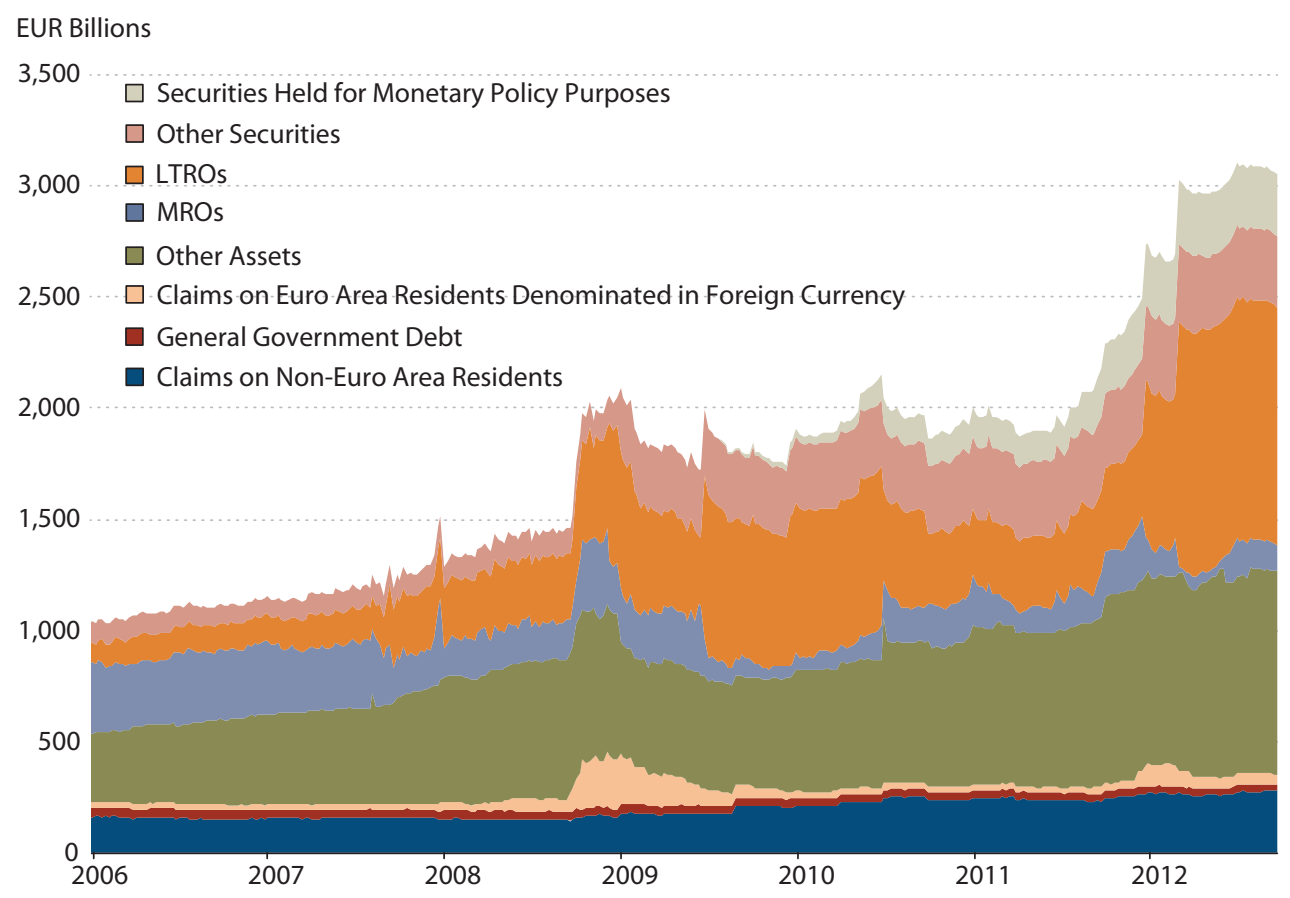

NOTE: Main (longer-term) refinancing operations are abbreviated MROs (LTROs). The ECB disaggregates its securities holdings into those held for monetary policy purposes, which include covered bond and sovereign debt purchases, and other securities. The figure shows the spike in lending (MROs and LTROs) following the availability of unlimited funds at the fixed rate in October 2008.

SOURCE: ECB.

maker of last resort quickly restored market functioning and the price floor established by the purchase programs did not bind for long. Ultimately, neither the Fed nor the BOE purchased large quantities of private assets. The BOE's private asset holdings peaked in 2009:Q2 at less than $£ 3$ billion, or 6 percent of the $£ 50$ billion ceiling announced in January 2009 . $\underline{21}$

On March 5, 2009, the BOE announced that the APF would administer an explicit QE program that targeted a $£ 75$ billion increase in the monetary base, which in later announcements (through November) would expand to $£ 200$ billion. The BOE’s Red Book states, "[T] he objective of Quantitative Easing is to boost the money supply through large-scale asset purchases and, in doing so, to bring about a level of nominal demand consistent with meeting the inflation target in the medium term" (BOE, 2012, p. 10). $\underline{22}$ The BOE directed QE purchases toward the deep and liquid markets in medium- and long-term gilts. To increase the monetary base, the BOE financed all new APF purchases by issuing money (central bank reserves) rather than issuing gilts. The short-term gilts issued to finance earlier purchases were allowed to mature without renewal, and by the end of 2009:Q2 bank reserves backed all assets held in the APF. 23 Figure 4 shows that the BOE's QE program almost quadrupled the U.K. monetary base within a few months as bond purchases replaced longer-term reverse repos. 


\section{Fawley and Neely}

\section{Figure $3 C$}

\section{BOE Assets}

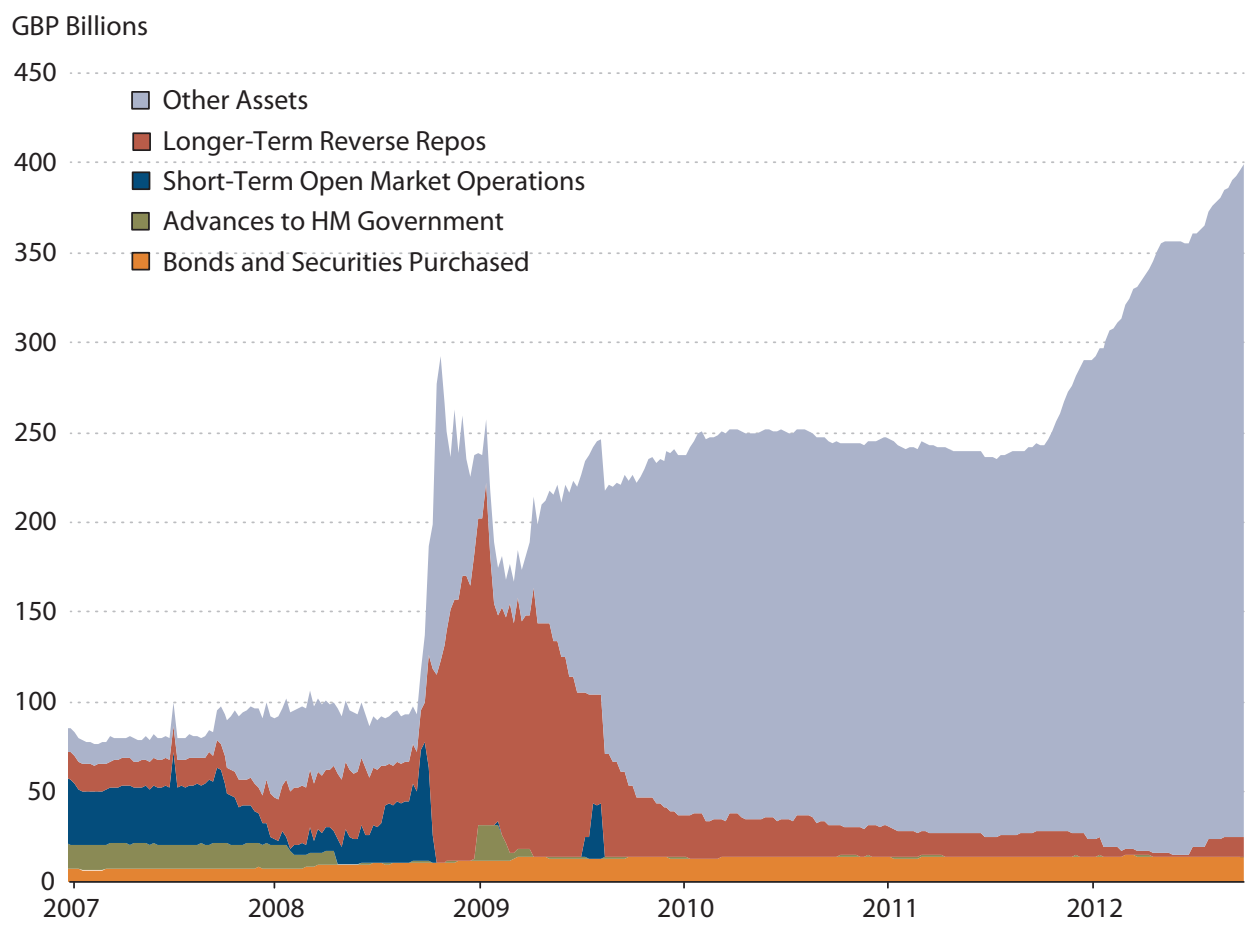

NOTE: Holdings of the Asset Purchase Facility are included in "Other Assets."

SOURCE: Bank of England.

The ECB Covered Bond Purchase Program. Despite the generous supply of (full-allotment) loans at low rates, concerns over counterparty risk continued to plague European interbank markets. $\stackrel{24}{ }$ By early 2009 lack of confidence in banks had dried up interbank lending (Beirne et al., 2011). The ECB - a relative latecomer to asset purchase programs - responded on May 7, 2009, by reducing its main refinancing rate to 1 percent and by introducing 12-month LTROs and the covered bond purchase program (CBPP). $\underline{25}$ The 12-month LTROs were created to address commercial bank preferences to borrow at longer maturities. Figure 3B illustrates an immediate and persistent shift away from MROs toward LTROs in May 2009. Covered bond purchases are included in the category "Securities Held for Monetary Policy Purposes" in Figure 3B.

What are covered bonds and how do they differ from other securities? Covered bonds differ from other asset-backed securities in two ways: (i) In the event of a bond default, covered bondholders have recourse to the issuer of the bond, as well as the underlying collateral pool (thus the term "covered"); and (ii) banks must hold the underlying collateral on their balance sheet, which reduces the incentives to make and securitize low-quality loans. Issuing long-maturity covered bonds helps banks to alleviate the maturity mismatch they usually face between the long-term loans they hold as assets and the on-demand deposits they hold as liabilities. These favorable characteristics helped the covered bond market to grow strongly and become an 


\section{Figure 3D}

\section{BOJ Assets}

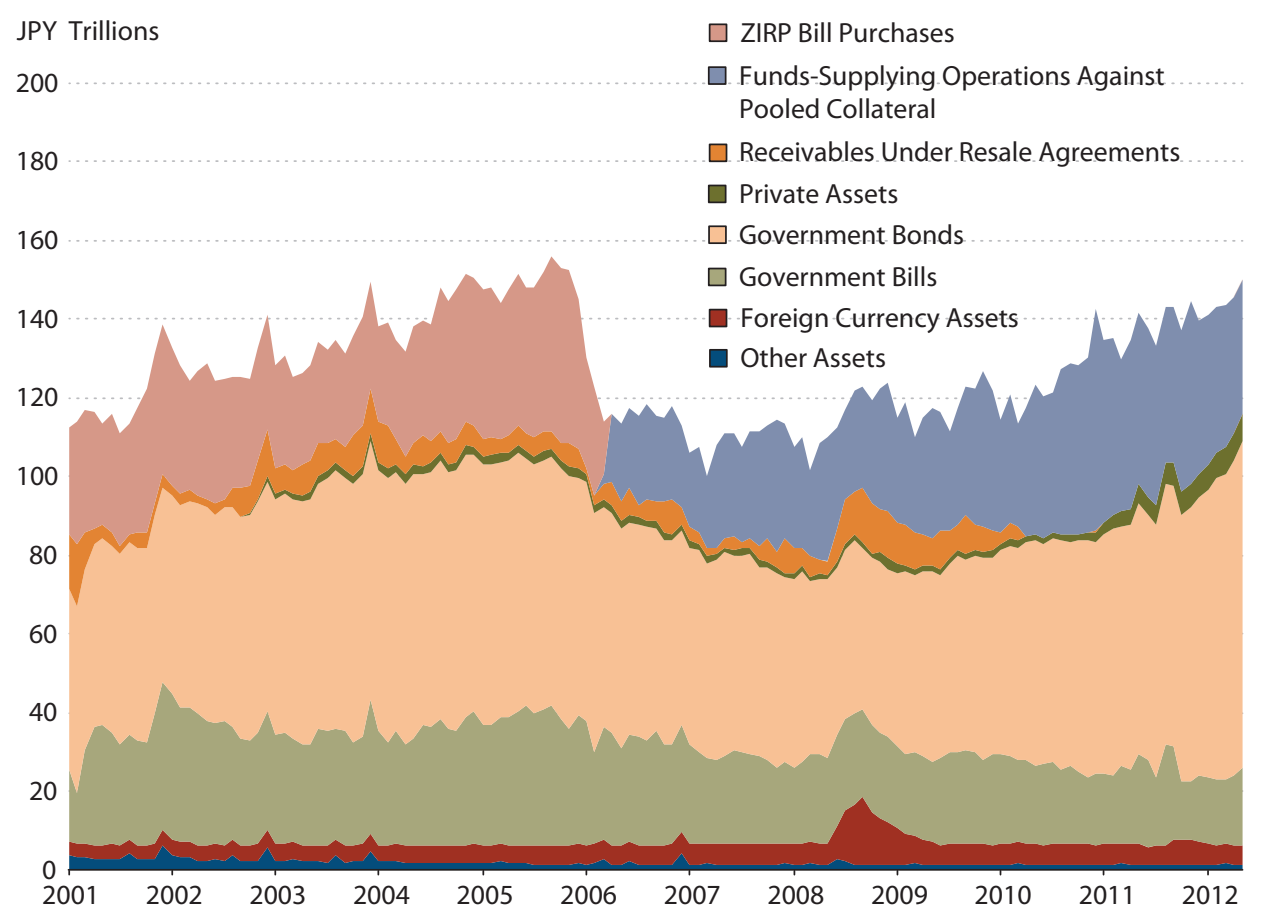

NOTE: "Government Bonds" includes monthly JGB purchases. "ZIRP Bill Purchases" includes public debt purchases made under Japan's ZIRP as part of its QE program in the early 2000s but excludes monthly JGB purchases. "Private Assets" includes all purchases of commercial paper, commercial bonds, ETFs, J-REITs, stocks, and MBS. On June 26, 2006, the BOJ introduced new electronic operations ("Funds-Supplying Operations Against Pooled Collateral") to replace conventional paper-based bill purchasing operations.

SOURCE: Bank of Japan.

important source of funding for European banks: from $€ 1.5$ trillion in 2003 to $€ 2.4$ trillion by the end of 2008 (Beirne et al., 2011).

Although the covered bond market functioned well throughout most of the financial crisis, the Lehman Brothers bankruptcy in September 2008 seriously impaired even this market. In response, on May 7, 2009, the ECB committed to purchase $€ 60$ billion in covered bonds, or roughly 2.5 percent of the outstanding bonds. Jean-Claude Trichet, then president of the ECB, adamantly maintained that the program was not QE and would not expand the ECB's balance sheet. Rather, Trichet stated that he expected "automatic sterilization" as the covered bond purchases would commensurately reduce demand for the elastically supplied LTROs. Trichet justified the program in terms of credit easing: "[T] he idea is to revive the market, which has been very heavily affected, and all that goes with this revival, including the spreads and the depth and the liquidity of the market." $\underline{6}$

The results of the CBPP and LTRO expansion were mixed. The $€ 60$ billion in ECB purchases stimulated $€ 150$ billion in issuance, though much of the new issuance represented a switch from uncovered bond to covered bond issuance. 27 ECB LTRO announcements failed to reduce credit 


\section{Fawley and Neely}

\section{Figure 4}

\section{Monetary Base and M2 Expansion}

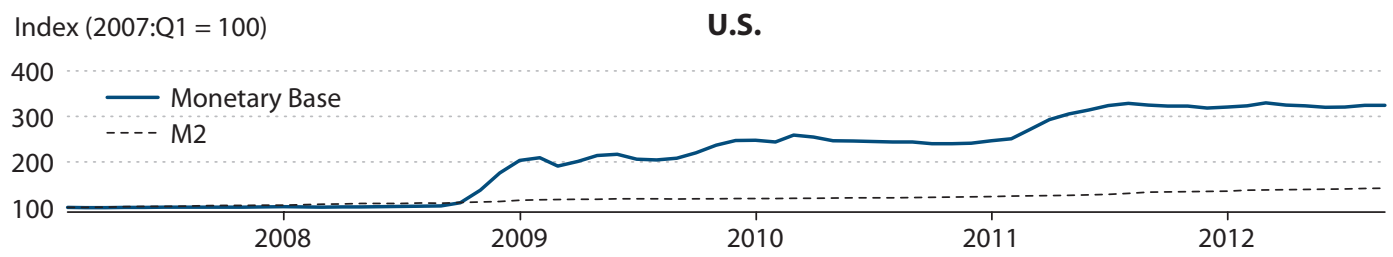

Index (2007:Q1 = 100) European Monetary Union
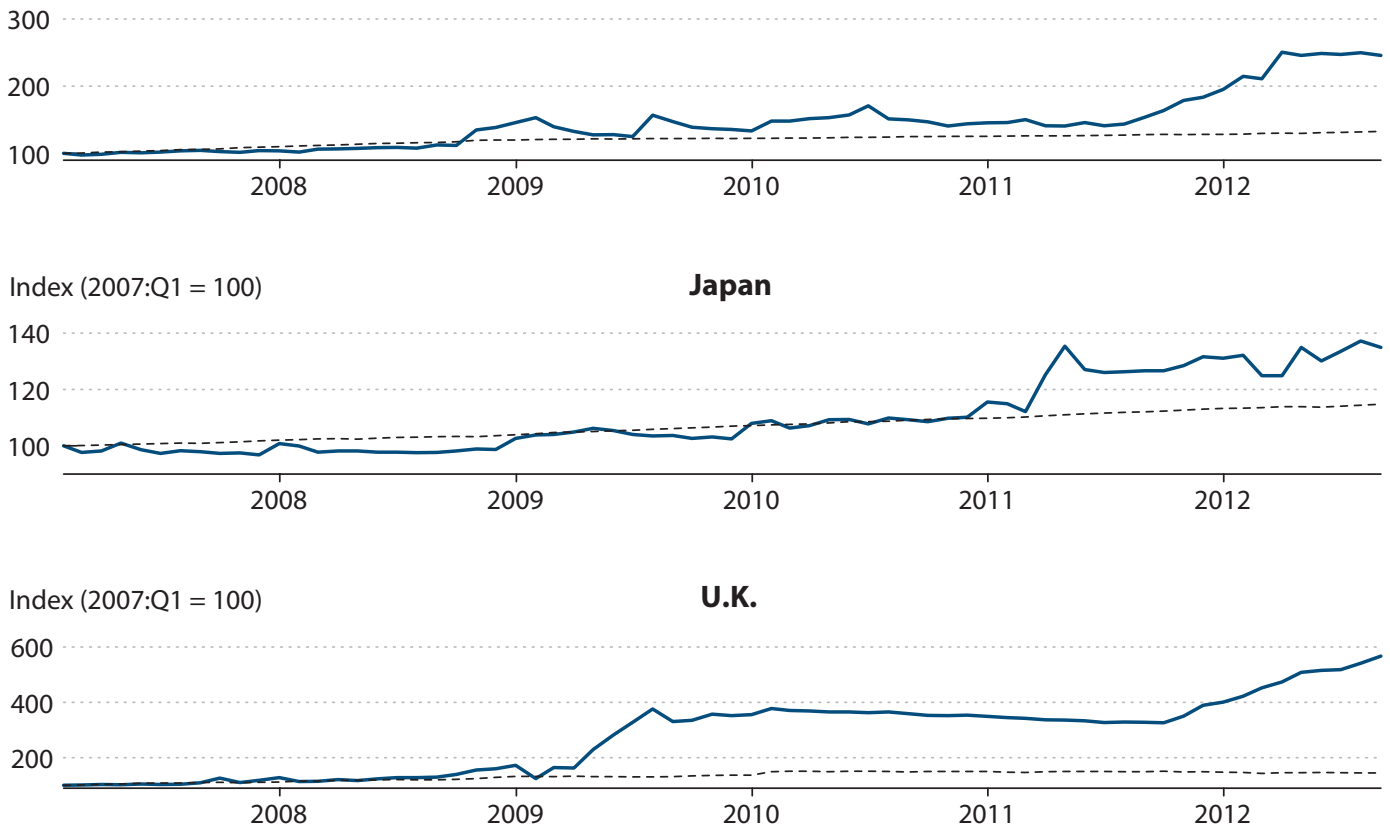

SOURCE: Federal Reserve Board, ECB, BOJ, and BOE.

risk, with one exception: The May 7, 2009, LTRO/CBPP announcement reduced credit default swap rates on the Markit iTraxx index of senior (subordinated) debt issued by the 25 largest European finance firms by roughly 28 (14) basis points.

BOJ Bond Purchases. The BOJ also expanded its FRFA bank loans into outright bond purchases. On December 19, 2008, the BOJ increased its monthly purchases of JGBs for the first time since October $2002 \frac{28}{2}$ and announced interest in purchasing corporate finance instruments. The $\mathrm{BOJ}$ followed up by announcing reverse-auction purchases of up to $¥ 3$ trillion in commercial paper and $¥ 1$ trillion in corporate bonds on January 22, 2009, and February 19, 2009, respectively. As with the Fed's and BOE's purchases of corporate finance instruments, the existence of a regular buyer increased prices by reducing liquidity risk; more buyers for the assets emerged and trade resumed. Offers to sell to the BOJ quickly diminished. On March 18, 2009, the BOJ increased JGB purchases to an annual rate of $¥ 21.6$ trillion. 
Summary. Although all four central banks announced outright asset purchases from the fall of 2008 through the spring of 2009, the Fed and BOE targeted large amounts of assets to purchase, but the ECB and BOJ chose to ease their monetary policy stance primarily by elastically supplying loans. Their outright asset purchases were generally small and targeted specific assets. The ECB's and BOJ's use of bank loans, rather than bond purchases, to expand the monetary base reflects both the desire to specifically support their banking sectors, hit hard by the financial crisis, and the relatively greater importance of banks, as opposed to bond markets, in Europe and Japan. At the end of 2007, the U.S. (European) stock of outstanding bank loans to the private sector totaled 63 percent (145 percent) of gross domestic product (GDP). By contrast, outstanding debt securities in the United States (Europe) accounted for 168 percent (81 percent) of GDP (Bini Smaghi, 2009).

One should note that elastic loan provision and bond purchase programs could affect asset prices differently: Bernanke (2002), for example, argues that low-cost loans will reduce risk premia and illiquidity in all assets that are eligible collateral, but public bond purchases will influence only the risk-free component of interest rates.

\section{Intermission (December 2009-July 2010)}

During the December 2009-July 2010 period, market conditions improved and the initial phase of the U.S. and U.K. QE programs announced in the fall of 2008 and spring of 2009 wound down, finishing by the end of 2010:Q1. At the same time, the BOJ and ECB backed off from elastically supplying liquidity. The European sovereign debt crisis, however, would soon prompt the ECB to resume asset purchase operations during this period.

The BOJ Ends SFSOs. On December 1, 2009, the BOJ announced fixed-rate operations (FROs) intended to replace the SFSOs—elastic provisioning of liquidity — set to expire at the end of 2010:Q1. FROs differed from SFSOs in that the loan quantities were fixed in the former, though a broader class of assets was eligible as collateral. The FROs were originally set at $¥ 10$ trillion in 3-month maturities and expanded to $¥ 20$ trillion in March 2010 as the SFSOs ended. An additional $¥ 10$ trillion was allocated to 6-month maturities on August 30, 2010.

The BOJ Opens the Growth-Supporting Funding Facility. On April 30, 2010, the BOJ announced that it was investigating possible ways to foster growth by providing funds directly to private financial institutions. The BOJ released a preliminary framework for the GrowthSupporting Funding Facility (GSFF) on May 21, 2010, and full details of the facility on June 15, 2010. Eligible FRO counterparties could submit proposals for investment or lending projects that would "support strengthening the foundations for economic growth." $\underline{29}$ Accepted proposals received 1-year loans, which through rollovers could be extended to a maximum of 4 years. The $\mathrm{BOJ}$ capped the quantity of loans at $¥ 3$ trillion and fixed the interest rate to the prevailing policy rate at origination.

The ECB Announces the Securities Markets Programme. In May 2010, the escalating sovereign debt crisis disrupted European financial markets (De Pooter, Martin, and Pruitt, 2012). On May 10, 2010, the ECB announced the Securities Markets Programme (SMP), which allowed

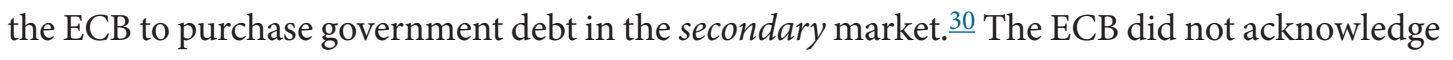
any intent to support the sovereign debt issuance of its member countries. Rather, it explained its motives for the SMP program as follows: "to ensure depth and liquidity in those market seg- 


\section{Fawley and Neely}

ments which are dysfunctional. The objective of this program is to address the malfunctioning of securities markets and restore an appropriate monetary policy transmission mechanism." 11

The SMP differed in several important dimensions from other asset purchase programs. First, the scope and size of the interventions were to be determined on an as-needed basis. Purchases were not preannounced but markets were left to infer whether the European Monetary Union was buying bonds until the following Tuesday when the ECB's balance sheet was released (De Pooter, Martin, and Pruitt, 2012). $\underline{32}$ Second, the ECB announced that the asset purchases would be sterilized to "ensure that the monetary policy stance [would] not be affected." For this purpose, the ECB would conduct "specific operations...to re-absorb the liquidity injected through the Securities Markets Programme." $\underline{3}$ Indeed, Figure 4 shows that the European Monetary Union monetary base did not increase from July 2010 to July 2011. Therefore, the SMP does not fall under the usual definition of QE.

The SMP purchases appear to have helped hold down yields on euro debt. In particular, observers credited ECB purchases with reducing yields on Spanish and Italian debt in August 2011. $\stackrel{34}{*}$ As of December 7, 2012, the ECB held $€ 208.5$ billion in euro area periphery sovereign debt accumulated under the SMP.

Given that the SMP purchases were sterilized and directed at markets whose functioning was unimpeded, except for concerns about the fundamental value of the assets, some would argue that the SMP amounted to credit rationing but not monetary policy. $\frac{35}{5}$

It is worth noting that the financial crisis, sovereign debt crisis, and banking problems in Europe are intimately linked. The financial crisis created a recession that reduced tax revenues and growth and raised social spending, thus significantly exacerbating existing budget problems and increasing the risk associated with European debt. Because banks traditionally hold substantial quantities of sovereign debt, riskier sovereign debt compromised the solvency of private banks and exacerbated information asymmetry in interbank markets. At the same time, the fact that governments insured bank deposits meant that bank failures would inevitably increase sovereign debt.

\section{QE Resumes (August 2010-Present)}

The Fed Pursues QE2. Serious financial market disorder had receded by the second half of 2010, but real activity remained sluggish. In particular, Figure 5 illustrates that the United States faced a worrisome disinflationary trend as U.S. consumer price index inflation dipped toward 1 percent. On August 10, 2010, the Fed announced that it would maintain the size of its balance sheet by reinvesting the principal payments on LSAP assets into Treasuries. The FOMC also began to signal that it was considering further asset purchases: In a speech on August 27, 2010, Chairman Bernanke suggested that the Fed could purchase more assets, should conditions warrant. The September 21, 2010, FOMC statement reiterated the concern that inflation was "likely to remain subdued for some time before rising to levels the Committee considers consistent with its mandate." Having signaled its intentions, the FOMC finally announced on November 3, 2010 , that it would purchase an additional $\$ 600$ billion in U.S. Treasuries to "promote a stronger pace of economic recovery and to help ensure that inflation, over time, is at levels consistent with its mandate." $\underline{36}$ 


\section{Figure 5}

\section{Year-over-Year Headline Inflation}

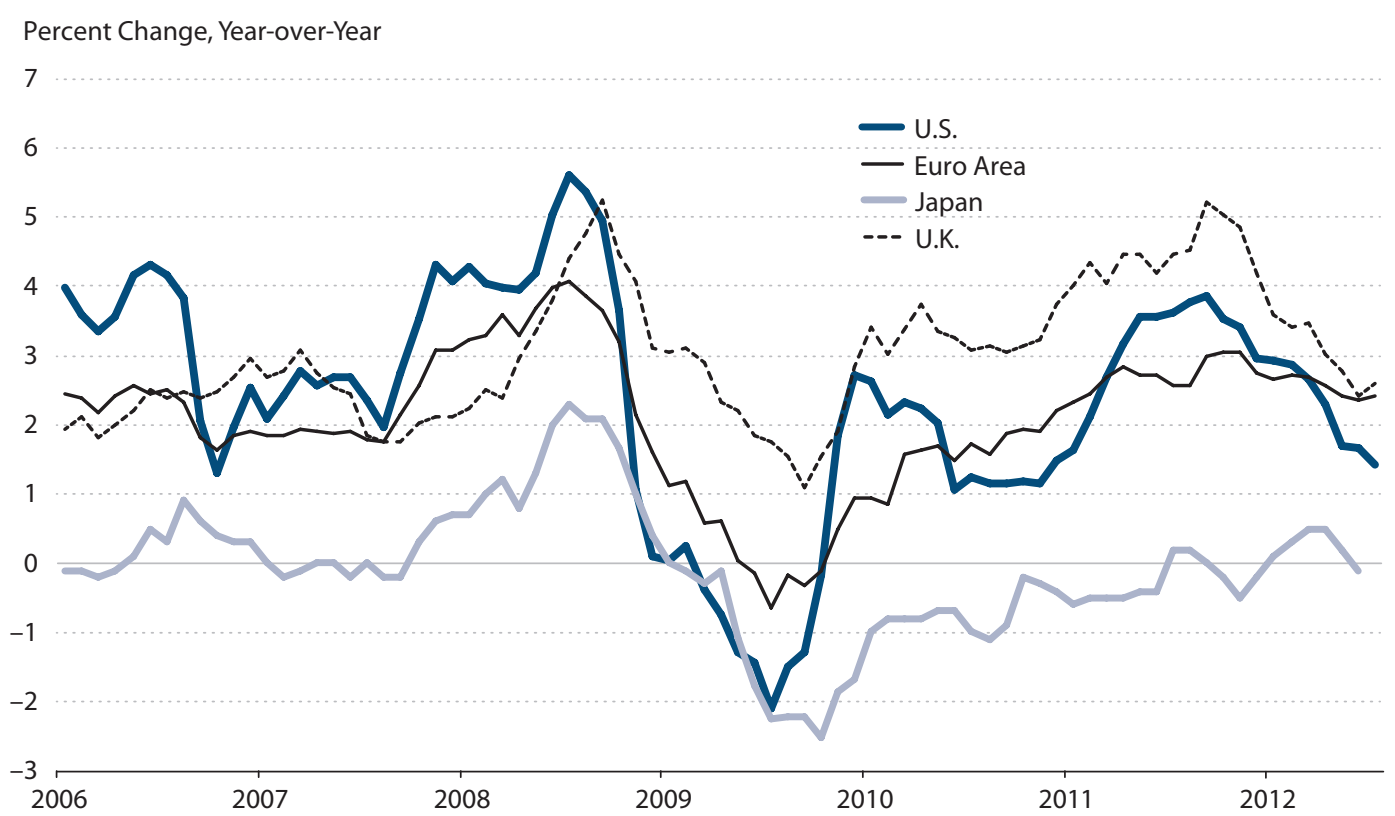

SOURCE: International Monetary Fund.

This program, usually called "QE2," was explicitly designed to lower long-term real interest rates and increase the inflation rate to levels deemed more consistent with the Fed's mandate from Congress. Figure 3A illustrates the growth in long-term Treasuries held by the Federal Reserve following this announcement, while Figure 4 shows the effect on the monetary base starting at the beginning of 2011.

Financial markets widely expected the November 2010 asset purchase announcement: In a Reuters poll conducted October 5, 2010, 16 of 16 primary dealers expected the Fed to ease monetary policy and 14 of 15 respondents expected the announcement to be made at the November 3 FOMC meeting. This anticipation meant that asset prices had already adjusted to these expectations and did not change much when the announcement finally came. $\frac{37}{3}$

The widespread expectation of renewed Fed asset purchases was in sharp contrast to the surprise that greeted Fed asset purchase announcements in November 2008 and March 2009. Neely (2012), for example, reports that 10-year constant maturity Treasury yields fell by a cumulative 94 basis points over the eight events that importantly shaped QE1 expectations. By contrast, 10-year yields cumulatively rose slightly around the set of important QE2 announcements. These patterns underscore the importance of evaluating program effectiveness based on the events that changed expectations of future purchases, which are not necessarily the events in which purchases were announced.

The BOJ Announces Comprehensive Monetary Easing. On October 5, 2010, the BOJ announced the Asset Purchase Program (APP) - similar to QE2, but broader-as part of a com- 


\section{Fawley and Neely}

prehensive monetary easing policy. Comprehensive monetary easing consisted of three measures: (i) lowering the target for the uncollateralized overnight call rate from 0.10 percent to $0-0.10$ percent, (ii) clarifying the conditions for exiting the ZIRP, and (iii) establishing the APP. The APP included plans to purchase a wide array of assets, including short- and long-term government securities, commercial paper, corporate bonds, exchange-traded funds (ETFs), and Japanese real estate investment trusts (J-REITs). $\underline{38}$ The BOJ purchased a range of private assetsrather than just public debt-to reduce the spread between private and (already very low) sovereign debt yields. The BOJ stated that the goal of its purchases was to "encourage the decline in longer-term interest rates and various risk premia to further enhance monetary easing." 39 The BOJ's targeting of private risk premia contrasted with the Fed's QE2 focus on long-term Treasuries to affect term premia. $\frac{40}{}$ The third panel of Figure 4 shows the monetary consequence of the APP as the rise in the monetary base in late 2010-early 2011.

The BOJ initially set the size of the APP at $¥ 35$ trillion, which included the existing $¥ 30$ trillion in FRO loans plus $¥ 5$ trillion in new asset purchases. In 2011, the BOJ increased the size of asset purchases by a total of $¥ 15$ trillion. On August 4, 2011, it added an additional $¥ 5$ trillion in 6-month loans through FROs.

The BOJ Expands the GSFF. On June 14, 2011, the BOJ extended the GSFF to include an additional $¥ 500$ billion credit line for investments in equity and asset-based lending. The loans had a 2-year maturity but could be rolled over only once.

The Fed Twists Again. The late summer of 2011 brought renewed fears of recession in the United States and financial stress indexes spiked. In response, the Fed announced a third round of long-term Treasury purchases, officially termed the Maturity Extension Program and Reinvestment Policy, on September 21, 2011. The program was nicknamed "Operation Twist" because the Fed sold $\$ 400$ billion in short-term assets while purchasing $\$ 400$ billion in long-term assets, which was intended to reduce long-term interest rates relative to short-term interest rates, thus "twisting" the yield curve. Operation Twist did not expand the monetary base because the long-term asset purchases were funded by short-term asset sales rather than money creation. At the same meeting, the FOMC also announced it would begin reinvesting maturing MBS and agency debt in MBS rather than Treasuries. $\underline{41}$

Central banks have tried similar programs before. The Federal Reserve famously attempted to influence the long end of the yield curve in a previous Operation Twist in the early 1960s. Modigliani and Sutch (1966) found that this earlier attempt to bring down long rates was, at best, moderately successful, probably because the purchases were insufficiently large and offset by new Treasury issuance (Blinder, 2000).

The ECB Extends LTROs/CBPP. The European sovereign debt crisis continued to disrupt European and U.S. markets in the fall of 2011. In response, on October 6, 2011, the ECB announced a second round of the CBPP and additional 12-month LTROs to provide bank funding. On December 8, 2011, the ECB announced auctions of 36-month LTROs. Figure 3B illustrates the increase in LTRO lending and covered bond purchases, while Figure 4 reveals their effect on the European Monetary Union monetary base.

Buiter and Rahbari (2012) speculate that the 36-month LTROs announced in December 2011 were not intended to merely provide liquidity, as was their stated purpose, but instead to inexpensively fund the purchase of sovereign debt while permitting the ECB to adhere to its 
charter. Regardless of whether the ECB intended the LTROs to support sovereign debt purchases, Buiter and Rahbari (2012) argue that various forms of financial repression have produced this result.

The BOE Extends QE. The BOE joined the ECB in acting on October 6, 2011. Concerned that it would undershoot its inflation target, the BOE increased the QE target from $£ 200$ billion to $£ 275$ billion - the first increase in purchases in nearly two years-increasing the monetary base to fund all APF purchases. On February 9, 2012, the BOE again increased the target, this time to $£ 325$ billion. With GDP contracting in 2011:Q4 and 2012:Q1, the BOE announced on July 5, 2012, that it would increase the size of QE yet again, to $£ 375$ billion. Figures $3 \mathrm{C}$ and 4 illustrate the renewed growth in BOE assets and the U.K. monetary base that began in late 2011 following the announcement of additional QE measures.

BOJ Expands APP/GSFF. In a fashion similar to that of the BOE, the BOJ also significantly increased its government debt purchases from fall 2011 through 2012. From October 2011 to December 2012, the BOJ announced an additional $¥ 60$ trillion in JGB and Treasury bill purchases and $¥ 1$ trillion in private asset purchases as part of its APP. .22 The BOJ also expanded the GSFF program on March 13, 2012 - from $¥ 3.5$ trillion to $¥ 5.5$ trillion一adding $¥ 1$ trillion in U.S.-dollardenominated loans and $¥ 0.5$ trillion in small-lot loans available in amounts as low as $¥ 1$ million. Perhaps as a result, the BOJ noted in its September 19, 2012, monetary policy announcement that "Japan's economy registered relatively high growth in the first half of 2012, supported by the firmness in domestic demand" but that inflation remains around 0 percent. $\underline{43}$

The Fed Extends Operation Twist, Introduces QE3. While Japan saw solid growth in the first half of 2012, U.S. nonfarm payrolls grew significantly slower than expected during the spring and summer. Speculation began to mount that the Fed would pursue additional easing.

On June 20, 2012, the Fed announced that it would extend its Maturity Extension Program that committed the Fed to buy long Treasuries and sell an equivalent quantity of short Treasuries through the end of the year. Final purchases under the Maturity Extension Program had originally been scheduled for the end of June. The additional purchases (and sales) continued at the same pace and were expected to total $\$ 267$ billion.

Despite this effort, the labor market remained sluggish. At his annual Jackson Hole speech, Chairman Bernanke acknowledged that "the stagnation of the labor market in particular is a grave concern" and that "the Federal Reserve will provide additional policy accommodation as needed." 44

As was widely expected, on September 13, 2012, the FOMC announced a third round of quantitative easing, or QE3. $\underline{45}$ Unlike in its previous QE programs, however, the Fed committed to a pace of purchases rather than a total quantity. It would purchase $\$ 40$ billion MBS per month and continue (or if warranted expand) purchases as long as "the outlook for the labor market does not improve substantially...in a context of price stability." 46 The conditional structure of the program reflects Bullard's (2010) argument that "analogous to interest rate policy, quantitative policy should be state contingent; that is, it should adjust to incoming information on the state of the economy."

On December 12, 2012, the FOMC announced that long-term Treasury purchases under the Maturity Extension Program would continue at the pace of $\$ 45$ billion/month, but such purchases would no longer be sterilized through the sale of short-term Treasuries. Hence, the 


\section{Fawley and Neely}

purchases previously made under the auspices of the Maturity Extension Program would continue, but with the additional effect of expanding the monetary base.

The ECB Replaces the SMP with Outright Monetary Transactions. The European sovereign debt crisis continued into the summer of 2012, with the solvency of Spain and Italy and the viability of the euro coming into question. On August 2, 2012, ECB President Mario Draghi announced that the ECB would expand its sovereign debt purchases and directly addressed concerns over the euro: "The euro is irreversible." 47

On September 6, 2012, the ECB announced the operational details for a program of outright monetary transactions (OMTs) to replace the SMP. $\stackrel{48}{*}$ The OMT program allows the ECB to purchase euro area sovereign debt in the secondary market if the sovereign abides by the required conditions. ${ }^{49}$ This requirement potentially addresses a shortcoming of the SMP: the ECB's lack of a mechanism for enforcing conditions for receiving support. As with the SMP transactions, the OMTs will be sterilized and will not affect the monetary base.

BOJ Reintroduces Unlimited Liquidity Provision. Despite relatively high growth in the first half of 2012, the Japanese economy once again contracted in the third quarter of 2012. On October 30, 2012, the BOJ announced an additional $¥ 11$ trillion in public and private asset purchases through the APP and that it was establishing a framework for the "Stimulating Bank Lending Facility" (SBLF). Through this facility, the BOJ offers to fund up to 100 percent of depository intuitions' net increase in lending to the nonfinancial sector. The loans are available at maturities of 1 to 3 years and can be rolled over to obtain a maximum duration of 4 years, with interest rates set equal to the target for the uncollateralized overnight call rate at the time of loan disbursement (0.1 percent as of December 2012). The only limit on the size of the loans is the quantity of eligible collateral, and in its December 20,2012, monetary policy statement the BOJ announced that based on current lending statistics, it expects to extend at least $¥ 15$ trillion in loans through the SBLF. Together, the SBLF and GSFF comprise what the BOJ calls the "Loan Support Program." $\underline{50}$

On December 16, 2012, Japan elected Shinzo Abe as its next prime minister. Abe campaigned on a platform of monetary policy accommodation to counteract deflationary conditions and advocates a 2 percent inflation target for the $\mathrm{BOJ}$ rather than the current 1 percent target. The new political regime has caused many to speculate that the BOJ's independence is at risk (e.g., Kihara, 2012).

Summary. In summary, from 2008 through 2012, three central banks (the BOE, BOJ, and ECB) purchased assets with private credit risk exposure, removing such risk from the public's

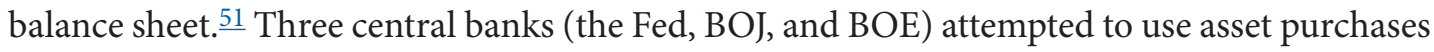
to stimulate the economy through traditional interest rate channels by purchasing long-term assets, reducing the amount of duration held by the public and thus lowering long-term real interest rates. All four central banks used asset purchases to improve the functioning of specific markets.

\section{ASSET PURCHASE PROGRAM SIZE AND BREAKDOWN}

This section describes and compares the sizes and composition of the asset purchase programs for the four central banks. Table 2 summarizes the size of asset purchase programs relative 
Fawley and Neely

\section{Table 2}

\section{Asset Purchase Program Size}

\begin{tabular}{|c|c|c|c|c|c|c|}
\hline Central bank & Program & Assets purchased & $\begin{array}{l}\text { Peak size } \\
\text { (billion NC) }\end{array}$ & $\begin{array}{c}\text { Peak size } \\
\text { (billion USD) }\end{array}$ & $\begin{array}{c}2008 \text { GDP } \\
\text { (billion NC) }\end{array}$ & $\begin{array}{c}\text { Share of } \\
\text { economy (\%) }\end{array}$ \\
\hline \multirow[t]{7}{*}{ Fed } & QE1 & GSE agency debt & $\$ 175$ & & $\$ 14,292$ & 1.2 \\
\hline & & MBS & $\$ 1,250$ & & & 8.7 \\
\hline & & Treasuries & $\$ 300$ & & & 2.1 \\
\hline & QE2 & Treasuries & $\$ 600$ & & & 4.2 \\
\hline & $\begin{array}{l}\text { Maturity Extension } \\
\text { Program }\end{array}$ & Treasuries & $\$ 667$ & & & 4.7 \\
\hline & QE3 & MBS & $\$ 160$ & & & 1.1 \\
\hline & & Treasuries & $\$ 0^{*}$ & & & 0.0 \\
\hline \multirow[t]{3}{*}{ BOE } & APF & Gilts & $£ 375$ & $\$ 590$ & $£ 1,441$ & 26.0 \\
\hline & & Commercial paper & $£ 1.97$ & $\$ 3.10$ & & 0.1 \\
\hline & & Corporate bonds & $£ 1.6$ & $\$ 2.52$ & & 0.1 \\
\hline \multirow[t]{3}{*}{$\mathrm{ECB}$} & CBPP & Covered bonds & $€ 60$ & $\$ 81$ & $€ 9,219$ & 0.7 \\
\hline & SMP & Euro area sovereign debt & $€ 220$ & $\$ 297$ & & 2.4 \\
\hline & CBPP2 & Covered bonds & $€ 40$ & $\$ 54$ & & 0.4 \\
\hline \multirow[t]{9}{*}{ BOJ } & Outright purchases & JGBs & $¥ 106,800$ & $\$ 1,253$ & $¥ 501,209$ & 21.3 \\
\hline & & Commercial paper & $¥ 3,000$ & $\$ 35$ & & 0.6 \\
\hline & & Corporate bonds & $¥ 1,000$ & $\$ 12$ & & 0.2 \\
\hline & APP & JGBs & $¥ 44,000$ & $\$ 516$ & & 8.8 \\
\hline & & Treasury discount bills & $¥ 24,500$ & $\$ 287$ & & 4.9 \\
\hline & & Commercial paper & $¥ 2,200$ & $\$ 26$ & & 0.4 \\
\hline & & Corporate bonds & $¥ 3,200$ & $\$ 38$ & & 0.6 \\
\hline & & ETFs & $¥ 2,100$ & $\$ 25$ & & 0.4 \\
\hline & & J-REITS & $¥ 130$ & $\$ 2$ & & 0.0 \\
\hline \multicolumn{3}{|l|}{ Fed total } & $\$ 3,152$ & $\$ 3,152$ & & 22.1 \\
\hline \multicolumn{3}{|l|}{ BOE total } & $£ 379$ & $\$ 596$ & & 26.3 \\
\hline \multicolumn{3}{|l|}{ ECB total } & $€ 320$ & $\$ 432$ & & 3.5 \\
\hline \multicolumn{3}{|l|}{ BOJ total } & $¥ 186,930$ & $\$ 2,193$ & & 37.3 \\
\hline \multicolumn{7}{|c|}{$\begin{array}{l}\text { NOTE: NC, national currency. Values in local currencies are converted to dollars using the average exchange rate with the dollar from January } \\
2009 \text { through November 2012. The Fed's monthly QE3 purchases and the BOJ's monthly outright JGB purchases, which are both open ended, } \\
\text { are aggregated through December 2012. *QE3 Treasury purchases were not announced until December 12, 2012, but will be made in } 2013 \text { at a } \\
\text { pace of } \$ 45 \text { billion per month. }\end{array}$} \\
\hline
\end{tabular}




\section{Fawley and Neely}

\section{Figure 6}

\section{BOE Asset Purchases by Type and Funding}
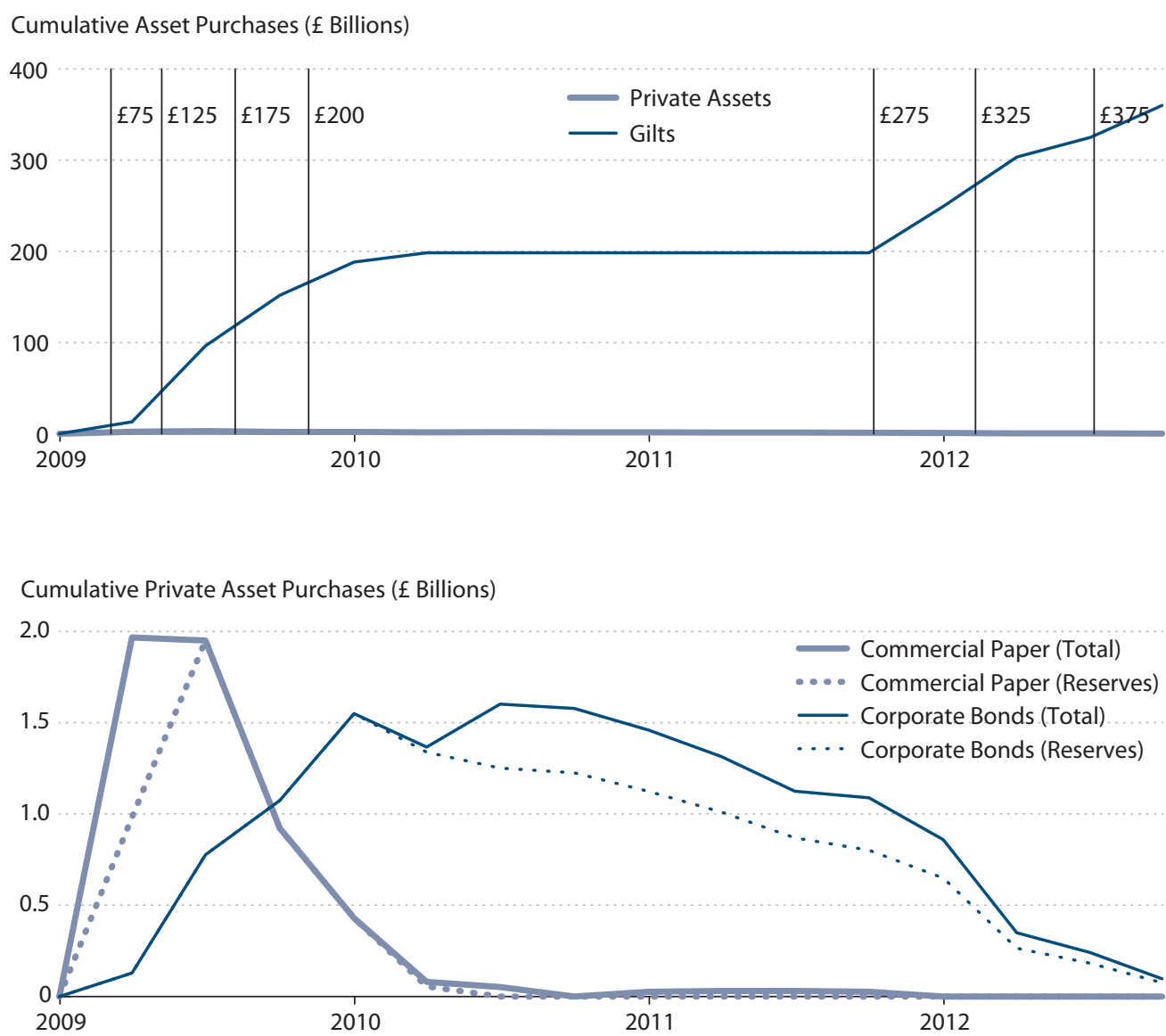

NOTE: Both panels show the outstanding balance of assets held in the APF of the BOE. The top panel distinguishes between total net purchases of public assets (gilts) and private assets (corporate bonds and commercial paper). The vertical lines mark asset purchase announcements; the newly announced size of the APF is shown to the right of the lines. The bottom panel shows the net purchases of private assets separated into commercial paper and corporate bonds. The solid lines show total net purchases; the dashed lines show net purchases funded by central bank reserve issuance. All gilt purchases in the top panel were funded by reserve issuance.

SOURCE: Bank of England Asset Purchase Facility Quarterly Reports.

to market and economy size. The Fed's asset purchase programs were the largest in absolute terms, but the BOJ programs were the largest as a percentage of domestic output.

\section{The Federal Reserve}

As of the end of 2012, the Federal Reserve has purchased \$1.567 trillion in long-term government bonds, \$1.41 trillion in MBS, and \$175 million in GSE debt, for a total of \$3.152 trillion in purchases. In addition, the Fed will continue to purchase MBS at a pace of $\$ 40$ billion per month and long-term Treasuries at a pace of $\$ 45$ billion per month in 2013. New reserve issuance has or will fund all these purchases, except for $\$ 667$ billion of Treasury purchases in Operation Twist that were funded by sales of shorter-term securities. 


\section{Figure 7}

\section{ECB Sovereign Debt Purchases}

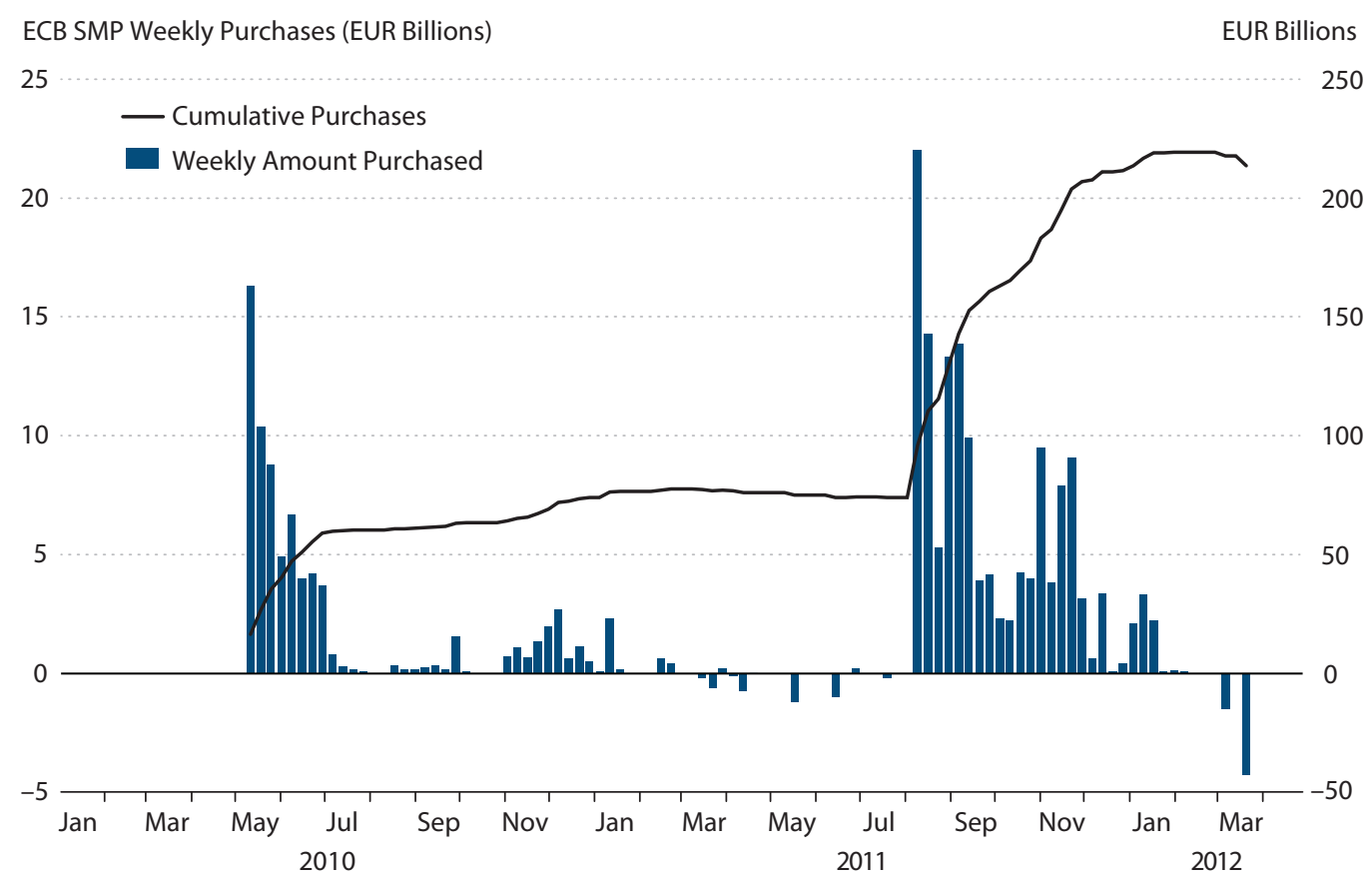

SOURCE: This figure is reproduced with permission from Figure 1 in De Pooter, Martin, and Pruitt (2012) and constructed from the ECB balance sheet, which is published at a weekly frequency (see www.ecb.int/press $/ \mathrm{pr} / \mathrm{wfs} / 2012 / \mathrm{html} / \mathrm{index}$.en.html).

The U.S. purchases can be separated into four distinct programs: QE1 (\$1.725 trillion, announcements 2008-09), QE2 (\$600 billion, announcement 2010), Operation Twist (\$667 billion, announcement 2011 and extension 2012), and QE3 (\$85 billion per month, announcements 2012). Since the initial purchases, the Federal Reserve has maintained the size of its balance sheet by reinvesting principal payments from maturing assets. Originally, all maturing assets were reinvested in Treasuries, but the FOMC later decided to reinvest maturing MBS and GSE debt in MBS. $\underline{52}$ Despite the approximate tripling of the monetary base (see Figure 4), the broader monetary aggregates have increased at healthy but normal rates because banks have chosen to greatly increase their desired levels of excess reserves.

\section{The Bank of England}

BOE QE asset purchase announcements can be categorized into two distinct episodes. In the first episode, the BOE initially announced a ceiling of $£ 75$ billion in purchases on March 5, 2009 , and then raised that ceiling to $£ 200$ billion by November 2009. On August 6, 2009, the $\mathrm{BOE}$ announced it would expand purchases into gilts with remaining maturities of 3 to 5 years and 25-plus years to accommodate the increased size of the purchases. On February 4, 2010, the first stage of purchases ended and the BOE announced that Treasury issuance, not money cre- 


\section{Fawley and Neely}

ation, would fund any new purchases, including any private asset purchases. The second stage of purchases began on October 6, 2011, when the BOE raised the asset purchase ceiling to $£ 275$ billion and announced that monetary expansion would again fund new purchases. The BOE expanded the APF again on February 9, 2012, and July 5, 2012, setting the ceiling at $£ 325$ and $£ 375$ billion, respectively.

In addition to the ceiling of $£ 375$ billion in assets financed by reserve issuance, the BOE is authorized to purchase up to $£ 10$ billion in private assets financed by Treasury issuance. $\frac{53}{}$ As the bottom panel of Figure 6 reveals, the BOE has never held more than $£ 3$ billion in private assetstotal commercial paper plus total corporate bonds-at quarter's end. The top panel of Figure 6 shows that gilt purchases accounted for almost all of the BOE's balance sheet expansion. At the close of 2012:Q3, the BOE held $£ 360$ billion in gilts and only $£ 100$ million in corporate bonds.

\section{The Bank of Japan}

The BOJ has purchased or made plans to purchase almost $¥ 187$ trillion in total assets over the January 2009-December 2012 period. Close to 40 percent of this quantity, however, is a legacy from the BOJ's QE policies in the early 2000s. The BOJ began purchasing JGBs (government bonds with maturities of 2 to 40 years) outright in the 1990s, and these monthly purchases reached $¥ 1.2$ trillion in 2002. Figure 3D shows that when the BOJ exited from QE in March 9, 2006, it reduced its balance sheet by letting short-term assets (ZIRP bills) mature without replacement. The BOJ kept purchasing JGBs at a pace of $¥ 1.2$ trillion per month, and the size of JGB holdings on the BOJ's balance sheet declined only gradually. $\underline{54}$ As of December 1, 2008, the BOJ was already purchasing $¥ 1.2$ trillion in JGBs per month under its previous policy. With no changes to this pace, the BOJ would have purchased $¥ 72$ trillion in JGBs from January 2008-December 2012 (60 months $\times ¥ 1.2$ trillion per month).

Since January 2009, the BOJ has purchased or made plans to purchase $¥ 115$ trillion in assets. Additional monthly JGB purchases, in excess of the $¥ 72$ trillion in JGBs that would have been purchased at the $¥ 1.2$ trillion per month pace, total $¥ 34.8$ trillion over the January 2008 December 2012 period. $\frac{55}{}$ The purchases of corporate financing instruments were much smaller, accounting for $¥ 4$ trillion in purchases, of which $¥ 3$ trillion was for commercial paper and $¥ 1$ trillion for corporate bonds.

The APP, announced in October 2010 and subsequently expanded on nine occasions, accounts for the remaining $¥ 76$ trillion in asset purchases. Of the $¥ 76$ trillion in assets that the BOJ cumulatively plans to purchase under the APP, $¥ 44$ trillion is in JGB, $¥ 24.5$ trillion in Japanese Treasury discount bills, $¥ 3.2$ trillion in corporate bonds, $¥ 2.2$ trillion in commercial

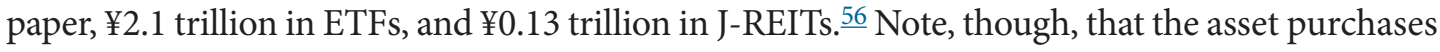
were announced in nine increments of $¥ 5$ trillion to $¥ 11$ trillion with varying asset composition. Since August 4, 2011, the BOJ has increased JGB and Treasury discount bill purchases by atot of $¥ 60$ trillion and private asset purchases by only $¥ 1.21$ trillion. As of December 2012, the BOJ intends to complete its announced APP purchases by the end of 2013. $\underline{\text { I7 }}$

\section{The European Central Bank}

The two ECB CBPPs have been comparatively modest in total size, though they represent larger purchases of private assets than any other central bank. The ECB announced the purchase 
of $€ 60$ billion in euro-denominated covered bonds in 2009 and $€ 40$ billion in similar purchases in 2011, for a total of $€ 100$ billion. The ECB never announced a target for sovereign debt purchases under the SMP, but the bank's balance sheet implies that these purchases cumulatively sum to around $€ 220$ billion at their peak. Figure 7 shows that the bulk of these purchases were made during two episodes: (i) the spring/summer of 2010 (with a focus on Greek, Irish, and Portuguese debt) and (ii) the summer to fall of 2011 (with a focus on Italian, Spanish, Portuguese, and Irish debt and no purchases of Greek debt). $\underline{58}$ The total ECB asset purchases-including sovereign debt purchases - total roughly $€ 320$ billion. As mentioned previously, most of these purchases have been sterilized, reversing their effects on the monetary base. The path of the European Monetary Union's monetary base reflects extensions of the LTRO program.

\section{CONCLUSION}

Central banks responded to the 2007-09 financial crisis with a series of policies that included emergency liquidity programs and reduction of their traditional short-term policy rates to near zero. Financial markets were still troubled, however; real output was declining or growing only sluggishly and inflation threatened to fall below central banks' desired levels. In response, the central banks of Japan, the United Kingdom, the United States, and the euro area responded with policies that greatly expanded their monetary bases, policies that are commonly called QE. These QE policies were potentially important to the extent that they allowed central banks to respond effectively to economic conditions - to ease credit conditions and provide liquidityeven with short-term interest rates near the zero bound.

The proliferating research on the effects of QE generally indicates that it had the desired effects on asset prices but the effects on the broader economy are much more difficult to discern because it is not possible to know with any certainty how economic conditions would have evolved without these policies in place. Despite the abundance of research on QE policies, there has been little description and international comparison of the policies of the four central banks that engaged in QE. This article has described those episodes of QE and compared policies across central banks.

The QE programs of these four major central banks initially attempted to reduce financial market distress, but they were soon used for a variety of purposes, including hitting inflation targets, stimulating the real economy, and containing the European sovereign debt crisis. Central banks with more bank-centric economies-the BOJ and ECB-responded with loans to the banking system, while those where bond markets are relatively more dominant-the Fed and $\mathrm{BOE}$ - responded with greater quantities of bond purchases.

A remarkable consistency among the monetary expansion policies of all four central banks is that while all measures led to sharp increases in the monetary base, none led to sharp increases in broader monetary aggregates (see Figure 4). The broader aggregates did not increase because banks voluntarily held the increased monetary base as bank reserves-safe, liquid assets in high demand during periods of economic uncertainty.

As of December 2012, interest rates are at or near historic lows in the major economies. As the effects of the housing bubble and financial crisis wane, however, interest rates will rise and monetary policy will eventually readjust to normal conditions. Although Fed purchases of spe- 


\section{Fawley and Neely}

cific non-Treasury securities will probably be reserved for unusual market dysfunction, it remains to be seen whether "normal" U.S. or foreign monetary policies will incorporate elements of the crisis policies, such as purchases of long-term assets. Given the emerging consensus in favor of transparent and predictable policy (Poole and Rasche, 2000), it seems likely there will be pressure to incorporate such strategies in conditional policy rules if they are to be used (Bullard, 2010).

\section{NOTES}

1 The fact that it is costly to store and protect large amounts of currency means that short-term rates can become slightly negative in some circumstances. Nevertheless, zero is a reasonable approximation on the lower bound for interest rates.

$\underline{2}$ Anderson, Gascon, and Liu (2010) survey a large cross section of central banks that have doubled their monetary base, but their work reflects only the first wave of the recent QE programs.

$\underline{3}$ In the context of borrowing and lending, "adverse selection" is the tendency of individuals and firms with bad credit to be more likely to seek loans from banks; and "moral hazard" is the tendency of borrowers to engage in risky activities that will make it less likely that they will repay their loans. Both adverse selection and moral hazard are problems because of the existence of "asymmetric information," which means that borrowers know things about their ability to repay that lenders do not.

4 In 2008 Congress granted the Federal Reserve the authority to begin paying interest on banks' excess reserves to improve the New York Fed's ability to manage the funds target and remove an implicit tax on holding reserves. This action did help to blur the distinction between money and bonds. The Federal Reserve could, however, increase the distinction between money and bonds by reducing or eliminating interest on excess reserves or even charging fees for excess reserves.

$\underline{5}$ Eggertsson and Woodford's (2003) model implies that a central bank should keep interest rates at the zero bound even after activity recovers to compensate for the fact that interest rates could not go below zero. This is subtly different from a commitment to be irresponsible.

$\underline{6}$ There is a potential downside to a commitment to low interest rates through asset purchases. The public might lose confidence in the central bank's ability to reverse asset purchases, which could unmoor inflation expectations (see, e.g., Anderson, Gascon, and Liu, 2010). An alternative is to purchase a carefully chosen portfolio of interest rate derivatives that would lose value if short-term interest rates increased faster than a time path announced by the central bank (see, e.g., Krippner and Thornton, 2012). Such a portfolio would be self-liquidating over time and profitable for the central bank if it kept its promise.

7 See the $12 / 16 / 2008,3 / 18 / 2009,8 / 09 / 2011,1 / 25 / 2012,9 / 13 / 2012$, and 12/12/2012 FOMC statements for the evolution of this language. Tables A 1 through A4 in the appendix provide URLs for the referenced policy statements and announcements for the Federal Reserve, European Central Bank, Bank of England, and Bank of Japan.

8 "Gilt" is a common name for U.K. government debt securities and alludes to the gilded (golden) edge of the paper bonds.

9 Baba, McCauley, and Ramaswamy (2009) detail these programs. Anderson and Mullineux (2009) describe some of the crisis response programs enacted by the BOE.

10 MMMFs take funds from investors and use those funds to purchase short-term fixed income securities such as U.S. Treasury bills, short-term commercial paper, and certificates of deposit. The bankruptcy of Lehman Brothers increased risk premia substantially, driving interest rates higher and making markets illiquid. To avoid losses, MMMF investors began withdrawing their money from the funds.

11 European OIS contracts are indexed to the Euro OverNight Index Average (EONIA), or the average uncollateralized rate that banks lend to each other overnight. Swap contracts are subject to very little counterparty risk because participants swap only the difference in interest payments between the agreed fixed rate and the geometric average of the indexed floating rate; there is no exchange of principal. In contrast, Euribor rates are quoted on fixed term loans between banks.

12 See www.ecb.int/home/glossary/html/glossf.en.html for the full definition of "fixed rate tender" and www.ecb.int/ecb/educational/facts/monpol/html/mp 010.en.html for "fixed-rate, full-allotment liquidity provision." 
13 The ECB announced the first 6-month LTRO in March 2008; see the 3/28/2008 ECB press release (Table A2).

14 In contrast to the Fed, $\mathrm{BO}$, and $\mathrm{BOE}$, the ECB's main policy rate is a 2-week rate, not an overnight rate. As in the United States, the overnight interbank rate in Europe has generally trended below 50 basis points since May 2009.

15 The GSEs include Fannie Mae, Freddie Mac, Ginnie Mae, and the Federal Home Loan Banks.

16 The Federal Reserve has referred to its purchase programs as LSAPs, but the generic term QE is more common in the financial press.

17 See the 11/25/2008 FOMC press release (Table A1). The purchases did not increase the exposure of U.S. taxpayers to these bonds, however, as the government had explicitly guaranteed all debts and liabilities of the GSEs earlier that fall, making the GSE debt and MBS close substitutes for long-term Treasury securities.

18 JGBs are bonds with 2 to 40 years remaining until maturity (see www.mof.go.jp/english/jgbs/debt management/guide.htm).

19 See the 1/19/2009 HM Treasury statement (Table A3).

$\underline{20}$ A reverse auction purchases items from low bidders rather than selling them to the highest bidder. HM Treasury indemnified the credit risk assumed by the BOE in purchasing private assets.

21 As the result of improved market conditions, the BOE ended the Commercial Paper Facility on November 15, 2011 (as it had announced it would one year earlier). The BOE continues to operate facilities for purchasing corporate bonds and secured commercial paper (www.bankofengland.co.uk/publications/Pages/news/2010/088.aspx).

$\underline{22}$ HM Treasury recognized immediately that the APF could be used in part as a monetary policy instrument: "[T]he programme also provides a framework for the Monetary Policy Committee [MPC] of the Bank of England to use asset purchases for monetary policy purposes should the MPC conclude that this would be a useful additional tool for meeting the inflation target." See the 1/19/2009 HM Treasury Statement (Table A3).

$\underline{23}$ See the Asset Purchase Facility Quarterly Report 2009 Q2 for a breakdown of assets held by method of financing (www.bankofengland.co.uk/publications/Pages/other/markets/apf/quarterlyreport.aspx).

24 Danielsson and de Vries (2008) assert that "extreme information asymmetry" with respect to banks' balance sheet health, not simply lack of liquidity, plagued interbank markets. They note that even a completely nationalized bank, Fortis in the Netherlands, had very limited access to interbank markets and that spreads between secured and unsecured lending indicated a market expectation that 1 in 20 of the big banks would fail.

$\underline{25}$ The maximum maturity of LTROs was first expanded from 3 to 6 months on March 28, 2008.

26 See the 5/7/2009 ECB press conference transcript (Table A2).

27 Many governments had issued formal guarantee programs to ensure demand for uncovered bonds.

$\underline{28}$ The BOJ had a preexisting bond purchase program established in the $1990 \mathrm{~s}$.

29 See the 6/15/2010 BOJ "Statement on Monetary Policy" (www.boj.or.jp/en/announcements/release_2010/k100615.pdf).

30 Article 123.1 of the Consolidated Version of the Treaty on the Functioning of the European Union prohibits the ECB from extending credit to the governments of its member states or directly purchasing sovereign debt in primary markets. See www.ecb.int/ecb/legal/pdf/fxac08115enc 002.pdf for the full treaty.

$\underline{31}$ See the 5/10/2010 ECB press release (Table A2).

$\underline{32}$ See www.ecb.int/press/pr/wfs/2012/html/index.en.html.

33 See the 5/10/2010 ECB press release (Table A2).

34 See Minder (2011). Figure 2 in De Pooter, Martin, and Pruitt (2012) shows heavy purchases of Italian and Spanish bonds in the second half of 2012.

35 In this context, a central bank might be accused of rationing credit if it directs loans or bond purchases to specific industries or types of economic activity, rather than supplying loans on the basis of risk-adjusted price or purchasing riskless government bonds.

$\underline{36}$ See the 11/3/2010 FOMC statement (Table A1). 


\section{Fawley and Neely}

37 On August 27, 2010, the date of Chairman Bernanke's speech, the 10-year constant maturity Treasury yield was 2.66 percent. The day after the Reuters poll, October 6, 2010, the 10-year constant maturity yield hit 2.41 percent, its lowest value since January 2009 and ultimately its lowest value of the year. By November 3, 2010, the day of the FOMC's QE2 announcement, the yield had returned to 2.67 percent and at the close of the year the yield had reached 3.30 percent.

$\underline{38}$ The purchase of ETFs and J-REITs was conditional upon receiving approval pursuant to the Bank of Japan Act.

39 See the 10/5/2010 BOJ press release (Table A4).

$\underline{40}$ Term premia are the excess yields that bond purchasers receive to hold long-term bonds rather than a series of short-term bonds. Risk premia are the excess yields on bonds that are perceived to have a greater risk of default.

41 This announcement had a significant effect on the MBS market. For example, in the first half of 2012 the Fed purchased close to 40 percent of the MBS issued by Fannie Mae and Freddy Mac and backed by 30-year conventional mortgages (Chandra and Strand, 2012).

$\underline{42}$ The BOJ simultaneously reduced the availability of FRO loans by $¥ 10$ trillion.

$\underline{43}$ See the 9/19/2012 BOJ press release (Table A4).

$\underline{44}$ See Bernanke (2012).

$\underline{45}$ At the July 31-August 1 FOMC meeting, "many members judged that additional monetary accommodation would likely be warranted fairly soon unless incoming information pointed to a substantial and sustainable strengthening in the pace of the economic recovery"; www.federalreserve.gov/monetarypolicy/files/fomcminutes20120801.pdf.

$\underline{46}$ See the 9/13/2012 FOMC statement (Table A1).

47 See the introductory statement to the ECB's press conference (www.ecb.int/press/pressconf/2012/html/is120802.en.html).

$\underline{48}$ Existing securities purchased under the SMP will be held to maturity.

$\underline{49}$ Through OMTs, the ECB will buy the debt of only those countries that have accepted aid from the European Stabilization Mechanism (ESM) and abided by its conditions. The ESM is a self-insurance fund capitalized by the euro area sovereigns and authorized to buy member sovereign debt on the primary market, conditional on the country's acceptance of a structural reform package.

$\underline{50}$ Based on current lending statistics, the BOJ expects to extend at least $¥ 50$ trillion in loans through the SBLF. On December 16, 2012, Japan elected Shinzo Abe as its next prime minister. Abe campaigned on a platform of monetary policy accommodation to counteract deflationary conditions and advocates a 2 percent inflation target for the BOJ rather than the current 1 percent target. The new political regime has caused many to speculate that the BOJ's independence is at risk (e.g., Kihara, 2012).

$\underline{51}$ Of course, the assets and liabilities of the government/central bank are ultimately assets and liabilities of taxpayers. But when central banks purchase private risk, the risk no longer affects marginal decisions of private agents.

$\underline{52}$ See 8/10/2010 and 9/21/2011 FOMC statements (Table A1).

$\underline{53}$ In a letter to Mervyn King, governor of the BOE, on November 29, 2011, George Osborne, chancellor of the Exchequer, lowered the ceiling on private asset purchases from $£ 50$ billion to $£ 10$ billion (Table A3). In total, HM Treasury indemnifies up to $£ 385$ billion in purchases through the APF, but no more than $£ 10$ billion in private assets and $£ 375$ billion in purchases funded by reserve issuance.

$\underline{54}$ Note that on June 26,2006 , the BOJ introduced new electronic operations called "funds-supplying operations against pooled collateral" to replace conventional paper-based bill purchasing operations.

$\underline{55}$ The BOJ expanded monthly JGB purchases first from $¥ 1.2$ trillion per month to $¥ 1.4$ trillion per month in December 2008 and then from $¥ 1.4$ trillion per month to $¥ 1.8$ trillion per month in March 2009; the $¥ 34.8$ trillion total equals 3 months $\times ¥ 0.2$ trillion per month +57 months $\times ¥ 0.6$ trillion per month. We measure the cumulative size of BOJ asset purchases in this subsection exclusively from purchases that have been made and are yet to be made but have a clearly defined (i.e., finite) size; we do not include anticipated monthly JGB purchases, which are set to continue indefinitely at a pace of $¥ 21.6$ trillion per year.

$\underline{56}$ See the 12/20/2012 BOJ release on the "Enhancement of Monetary Easing" (Table A4).

57 See the 12/20/2012 BOJ release for information about the pace of purchases (Table A4).

$\underline{58}$ See Figures 1 and 2 in De Pooter, Martin, and Pruitt (2012). 


\section{REFERENCES}

Anderson, Richard G. and Mullineux, Andrew W. "British Banking in Crisis." Federal Reserve Bank of St. Louis Economic Synopses, 2009, No. 16, April 3, 2009; http://research.stlouisfed.org/publications/es/09/ES0916.pdf.

Anderson, Richard G.; Gascon, Charles S. and Liu, Yang. “Doubling Your Monetary Base and Surviving: Some International Experience." Federal Reserve Bank of St. Louis Review, November/December 2010, 92(6), pp. 481-505; http://research.stlouisfed.org/publications/review/10/11/Anderson.pdf.

Baba, Naohiko; McCauley, Robert N. and Ramaswamy, Srichander. “U.S. Dollar Money Market Funds and non-U.S. Banks." BIS Quarterly Review, March 2009, pp. 65-81.

Bank of England. "The Framework for the Bank of England's Operations in the Sterling Money Markets" [The Red Book]. Updated June 2012; www.bankofengland.co.uk/markets/Documents/money/publications/redbookjune2012.pdf.

Beirne, John; Dalitz, Lars; Ejsing, Jacob; Grothe, Magdalena; Manganelli, Simone; Monar, Fernando; Sahel, Benjamin; Sušec, Matjaž; Tapking, Jens and Vong, Tana. "The Impact of the Eurosystem's Covered Bond Purchase Programme on the Primary and Secondary Markets." ECB Occasional Paper Series No. 122, European Central Bank, January 2011; www.ecb.int/pub/pdf/scpops/ecbocp122.pdf.

Bernanke, Ben S. "Deflation: Making Sure 'It' Doesn't Happen Here." Speech at the National Economists Club, Washington, DC, November 21, 2002; www.federalreserve.gov/boarddocs/speeches/2002/20021121/default.htm.

Bernanke, Ben S. "The Crisis and the Policy Response." Speech at the Stamp Lecture, London School of Economics, London, England, January 13, 2009; www.federalreserve.gov/newsevents/speech/bernanke20090113a.htm.

Bernanke, Ben S. "Monetary Policy Since the Onset of the Crisis." Presented at a symposium sponsored by the Federal Reserve Bank of Kansas City, "The Changing Policy Landscape," Jackson Hole, Wyoming, August 31, 2012; www.federalreserve.gov/newsevents/speech/bernanke20120831a.htm

Bini Smaghi, Lorenzo. "Conventional and Unconventional Monetary Policy." Keynote speech at the International Center for Monetary and Banking Studies, Geneva, Switzerland, April 28, 2009; www.bis.org/review/r090429e.pdf?frames $=0$.

Blinder, Alan S. "Monetary Policy at the Zero Lower Bound: Balancing the Risks." Journal of Money, Credit, and Banking, November 2000, 32 (4 Part 2), pp. 1093-99.

Buiter, Willem H. and Rahbari, Ebrahim. "The ECB as Lender of Last Resort for Sovereigns in the Euro Area." CEPR Discussion Paper No. 8974, Centre for Economic Policy Research, May 2012; http://willembuiter.com/lolr.pdf.

Bullard, James. "Three Lessons for Monetary Policy from the Panic of 2008." Federal Reserve Bank of St. Louis Review, May/June 2010, 92(3), pp. 155-63; http://research.stlouisfed.org/publications/review/10/05/Bullard.pdf.

Chandra, Lokesh and Strand, Nicholas. "Fed Agency MBS Purchases as of October 3, 2012." Barclays Securitisation Research, October 4, 2012.

Danielsson, Jon and de Vries, Casper. "Money Market on Strike." Economists' Forum (blog), Financial Times, November 9 2008; blogs.ft.com/economistsforum/2008/11/money-market-on-strike/\#axzz291ASfhQv.

De Pooter, Michiel; Martin, Robert F. and Pruitt, Seth. "A European Twist: The Efficacy of the Securities Markets Programme." Unpublished manuscript, Federal Reserve Board of Governors, March 2012.

Eggertsson, Gauti B. "The Deflation Bias and Committing to Being Irresponsible." Journal of Money, Credit, and Banking, March 2006, 38(2), pp. 283-321.

Eggertsson, Gauti B. and Woodford, Michael. "The Zero Bound on Interest Rates and Optimal Monetary Policy." Brookings Papers on Economic Activity, 2003, 1, pp. 139-211.

Gagnon, Joseph; Raskin, Matthew; Remache, Julie and Sack, Brian. “Large-Scale Asset Purchases by the Federal Reserve: Did They Work?" Federal Reserve Bank of New York Economic Policy Review, May 2011a, 17(1), pp. 41-59; www.newyorkfed.org/research/epr/11v17n1/1105gagn.pdf.

Gagnon, Joseph; Raskin, Matthew; Remache, Julie and Sack, Brian. "The Financial Market Effects of the Federal Reserve's Large-Scale Asset Purchases." International Journal of Central Banking, March 2011b, 7(1), pp. 3-43.

Hamilton, James D. and Wu, Jing C. "The Effectiveness of Alternative Monetary Policy Tools in a Zero Lower Bound Environment." NBER Working Paper 16956, National Bureau of Economic Research, April 2011;

www.nber.org/papers/w16956.pdf?new window=1. 


\section{Fawley and Neely}

Ito, Takatoshi and Mishkin, Frederic S. "Two Decades of Japanese Monetary Policy and the Deflation Problem," in Takatoshi Ito and Andrew Rose, eds., Monetary Policy under Very Low Inflation in the Pacific Rim. National Bureau of Economic Research-East Asia Seminar on Economics, September 2006. Volume 15. Chicago: University of Chicago Press, 2006, pp. 131-93.

Joyce, Michael A.S.; Lasaosa, Ana; Stevens, Ibrahim and Tong, Matthew. "The Financial Market Impact of Quantitative Easing in the United Kingdom." International Journal of Central Banking, September 2011, 7(3), pp. 113-61.

Keynes, John Maynard. General Theory of Employment, Interest and Money. London: McMillan and Company, 1936.

Kihara, Leika. "Under Pressure from Abe, Bank of Japan Boosts Stimulus Again." Reuters, December 20, 2012; www.reuters.com/article/2012/12/20/us-japan-economy-idUSBRE8BJ05520121220.

Kohn, Donald L. "Monetary Policy Research and the Financial Crisis: Strengths and Shortcomings." Speech at the Federal Reserve Conference on Key Developments in Monetary Policy, Washington DC, October 9, 2009; www.federalreserve.gov/newsevents/speech/kohn20091009a.htm.

Krippner, Leo and Thornton, Daniel T. "A Proposal for Improving Forward Guidance." Federal Reserve Bank of St. Louis Economic Synopses, 2012, No. 27, September 28, 2012; http://research.stlouisfed.org/publications/es/12/ES 27 2012-09-28.pdf.

Meyer, Laurence H. and Bomfim, Antulio N. "Quantifying the Effects of Fed Asset Purchases on Treasury Yields." Macroeconomic Advisers Monetary Policy Insights: Fixed Income Focus, June 17, 2010.

Minder, Raphael. "Spanish and Italian Bond Yields Drop on E.C.B. Buying." New York Times, August 9, 2011; www.nytimes.com/2011/08/10/business/global/spanish-and-italian-bond-yields-drop-on-ecb-buying.html? r=0.

Mishkin, Frederic S. "The Channels of Monetary Transmission: Lessons for Monetary Policy." NBER Working Paper No. 5464, National Bureau of Economic Research, February 1996; www.nber.org/papers/w5464.pdf?new window=1.

Neely, Christopher J. "The Large-Scale Asset Purchases Had Large International Effects." Federal Reserve Bank of St. Louis Working Paper No. 2010-018D, July 2010, revised April 2012; http://research.stlouisfed.org/wp/2010/2010-018.pdf.

Modigliani, Franco and Sutch, Richard. "Innovations in Interest Rate Policy." American Economic Review, March 1966, 56(1-2), pp. 178-97.

Poole, William and Rasche, Robert. "Perfecting the Market's Knowledge of Monetary Policy." Journal of Financial Services Research, 2000, 18(2-3), pp. 255-98.

Stroebel, Johannes C. and Taylor, John B. "Estimated Impact of the Fed's Mortgage-Backed Securities Purchase Program." NBER Working Paper No. 15626, National Bureau of Economic Research, December 2009; www.nber.org/papers/w15626.pdf?new window=1. 


\section{APPENDIX}

\section{Policy Statement URLs}

The appendix tables provide URLs for the official policy statements included in Tables 1A-1D and discussed in the text.

\section{Table A1}

\section{URLs for Relevant Federal Reserve Policy Statements}

\section{Date}

$11 / 25 / 2008$

$12 / 16 / 2008$

$1 / 28 / 2009$

$3 / 18 / 2009$

$8 / 12 / 2009$

$9 / 23 / 2009$

$11 / 4 / 2009$

$8 / 10 / 2010$

$9 / 21 / 2010$

$11 / 3 / 2010$

$6 / 22 / 2011$

$8 / 9 / 2011$

$9 / 21 / 2011$

$1 / 25 / 2012$

$6 / 20 / 2012$

$9 / 13 / 2012$

$12 / 12 / 2012$
Program

QE1

QE1/extended period language

QE1

QE1/extended period language

QE1

QE1

QE1

QE1

QE2

QE2

QE2

Extended period language Maturity Extension Program Extended period language Maturity Extension Program QE3/extended period language

QE3/extended period language
URL

www.federalreserve.gov/newsevents/press/monetary/20081125b.htm www.federalreserve.gov/newsevents/press/monetary/20081216b.htm

www.federalreserve.gov/newsevents/press/monetary/20090128a.htm www.federalreserve.gov/newsevents/press/monetary/20090318a.htm www.federalreserve.gov/newsevents/press/monetary/20090812a.htm www.federalreserve.gov/newsevents/press/monetary/20090923a.htm www.federalreserve.gov/newsevents/press/monetary/20091104a.htm www.federalreserve.gov/newsevents/press/monetary/20100810a.htm www.federalreserve.gov/newsevents/press/monetary/20100921a.htm www.federalreserve.gov/newsevents/press/monetary/20101103a.htm www.federalreserve.gov/newsevents/press/monetary/20110622a.htm www.federalreserve.gov/newsevents/press/monetary/20110809a.htm www.federalreserve.gov/newsevents/press/monetary/20110921a.htm www.federalreserve.gov/newsevents/press/monetary/20120125a.htm www.federalreserve.gov/newsevents/press/monetary/20120620a.htm www.federalreserve.gov/newsevents/press/monetary/20120913a.htm www.federalreserve.gov/newsevents/press/monetary/20121212a.htm

\section{Table A2}

\section{URLs for Relevant European Central Bank Policy Statements}

\begin{tabular}{lll} 
Date & Program & URL \\
\hline $\begin{array}{l}\text { 3/28/2008 } \\
10 / 15 / 2008\end{array}$ & $\begin{array}{l}\text { LTRO } \\
\text { Fixed-rate tender, } \\
\text { full allotment }\end{array}$ & www.ecb.eu/press/pr/date/2008/html/pr080328.en.html \\
5/7/2009 & CBPP/LTRO & www.ecb.eu/press/pr/date/2008/html/pr081015.en.html \\
$5 / 10 / 2010$ & SMP & www.ecb.eu/press/pr/date/2010/html/pr100510.en.html \\
6/30/2010 & CBPP & www.ecb.eu/press/pr/date/2010/html/pr100630.en.html \\
$10 / 6 / 2011$ & CBPP2 & www.ecb.eu/press/pr/date/2011/html/pr111006 3.en.html \\
$12 / 8 / 2011$ & LTRO & www.ecb.eu/press/pr/date/2011/html/pr111208 1.en.html \\
$9 / 6 / 2012$ & OMT & www.ecb.eu/press/pr/date/2012/html/pr120906 1.en.html
\end{tabular}




\section{Fawley and Neely}

\section{Table A3}

\section{URLs for Relevant Bank of England (and HM Treasury) Policy Statements}

\begin{tabular}{|c|c|c|}
\hline Date & Program & URL \\
\hline $1 / 19 / 2009$ & APF & $\begin{array}{l}\text { webarchive.nationalarchives.gov.uk/20100407010852/ } \\
\text { www.hm-treasury.gov.uk/press_05_09.htm }\end{array}$ \\
\hline $3 / 5 / 2009$ & APF & www.bankofengland.co.uk/publications/Pages/news/2009/019.aspx \\
\hline $5 / 7 / 2009$ & APF & www.bankofengland.co.uk/publications/Pages/news/2009/037.aspx \\
\hline $8 / 6 / 2009$ & APF & www.bankofengland.co.uk/publications/Pages/news/2009/063.aspx \\
\hline $11 / 5 / 2009$ & APF & www.bankofengland.co.uk/publications/Pages/news/2009/081.aspx \\
\hline $11 / 29 / 2011$ & APF & www.hm-treasury.gov.uk/d/chx letter 291111.pdf \\
\hline 2/4/2010 & APF & www.bankofengland.co.uk/publications/Pages/news/2010/008.aspx \\
\hline 10/6/2011 & APF & www.bankofengland.co.uk/publications/Pages/news/2011/092.aspx \\
\hline $11 / 29 / 2011$ & APF & www.hm-treasury.gov.uk/d/chx letter 291111.pdf \\
\hline 2/9/2012 & APF & www.bankofengland.co.uk/publications/Pages/news/2012/008.aspx \\
\hline $7 / 5 / 2012$ & APF & www.bankofengland.co.uk/publications/Pages/news/2012/066.aspx \\
\hline
\end{tabular}

\section{Table A4}

\section{URLs for Relevant Bank of Japan Policy Statements}

\begin{tabular}{|c|c|c|}
\hline Date & Program & URL \\
\hline $12 / 2 / 2008$ & SFSOs & www.boj.or.jp/en/announcements/release 2008/un0812b.pdf \\
\hline $12 / 19 / 2008$ & Outright JGB/CFI purchases & www.boj.or.jp/en/announcements/release_2008/k081219.pdf \\
\hline $1 / 22 / 2009$ & Outright CFI purchases & www.boj.or.jp/en/announcements/release 2009/mok0901a.pdf \\
\hline $2 / 19 / 2009$ & Outright CFI purchases & www.boj.or.jp/en/announcements/release 2009/mok0902b.pdf \\
\hline 3/18/2009 & Outright JGB purchases & www.boj.or.jp/en/announcements/release 2009/k090318.pdf \\
\hline 7/15/2009 & Outright CFI purchases/SFSOs & www.boj.or.jp/en/announcements/release 2009/k090715.pdf \\
\hline 10/30/2009 & Outright CFI purchases/SFSOs & www.boj.or.jp/en/announcements/release 2009/k091030.pdf \\
\hline $12 / 1 / 2009$ & FROs & www.boj.or.jp/en/announcements/release 2009/k091201.pdf \\
\hline $3 / 17 / 2010$ & FROs & www.boj.or.jp/en/announcements/release_2010/k100317.pdf \\
\hline $5 / 21 / 2010$ & GSFF & www.boj.or.jp/en/announcements/release 2010/k100521.pdf \\
\hline $8 / 30 / 2010$ & FROs & www.boj.or.jp/en/announcements/release 2010/k100830.pdf \\
\hline $10 / 5 / 2010$ & APP & www.boj.or.jp/en/announcements/release 2010/k101005.pdf \\
\hline $3 / 14 / 2011$ & APP & www.boj.or.jp/en/announcements/release 2011/k110314a.pdf \\
\hline $6 / 14 / 2011$ & GSFF & www.boj.or.jp/en/announcements/release 2011/k110614a.pdf \\
\hline $8 / 4 / 2011$ & APP/FROs & www.boj.or.jp/en/announcements/release 2011/k110804a.pdf \\
\hline $10 / 27 / 2011$ & APP & www.boj.or.jp/en/announcements/release_2011/k111027a.pdf \\
\hline 2/14/2012 & APP & www.boj.or.jp/en/announcements/release 2012/k120214a.pdf \\
\hline $3 / 13 / 2012$ & GSFF & www.boj.or.jp/en/announcements/release 2012/k120313a.pdf \\
\hline $4 / 27 / 2012$ & APP/FROs & www.boj.or.jp/en/announcements/release 2012/k120427a.pdf \\
\hline $7 / 12 / 2012$ & APP/FROs & www.boj.or.jp/en/announcements/release 2012/k120712a.pdf \\
\hline 9/19/2012 & APP & www.boj.or.jp/en/announcements/release 2012/k120919a.pdf \\
\hline 10/30/2012 & APP/SBLF & www.boj.or.jp/en/announcements/release 2012/k121030a.pdf \\
\hline $12 / 20 / 2012$ & APP & www.boj.or.jp/en/announcements/release_2012/k121220a.pdf \\
\hline
\end{tabular}

NOTE: CFI, corporate finance instruments (corporate bonds plus commercial paper). 